\title{
36
}

\section{Recent Advances in Real-Time Mass Spectrometry Detection of Bacteria}

\author{
Arjan L. van Wuijckhuijse and Ben L.M. van Baar
}

\begin{abstract}
The analysis of bio-aerosols poses a technology challenge, particularly when sampling and analysis are done in situ. Mass spectrometry laboratory technology has been modified to achieve quick bacteria typing of aerosols in the field. Initially, aerosol material was collected and subjected off-line to minimum sample treatment and mass spectrometry analysis. More recently, sampling and analysis were combined in a single process for the real-time analysis of bio-aerosols in the field. This chapter discusses the development of technology for the mass spectrometry of bio-aerosols, with a focus on bacteria aerosols. Merits and drawbacks of the various technologies and their typing signatures are discussed. The chapter concludes with a brief view of future developments in bio-aerosol mass spectrometry.
\end{abstract}

\section{Introduction}

\subsection{General}

Real-time detection of biological material with absolute identity determination is the stuff of science fiction. In this case, science fiction actually represents the "market pull" that challenges a "technology push." As concerns the real-time analysis of biological aerosols, the challenge was taken up in the mid 1980s, when some of the technology seemed sufficiently mature for integration in a universally applicable real-time bio-aerosol mass spectrometer. Two decades later, direct bio-aerosol mass spectrometry is still in the early stages of technology development, with research going on in a few select institutes. In the same two decades, the "market pull" of science fiction was fortified by an increasing awareness of biological threat, propelled by possibly emerging pandemics (e.g., Perdue and Swayne 2005; Glass and Becker 2006), and by the fear of bioterrorist attacks (e.g., Hamburg 2002; Tegnell et al. 2006). By now, mass spectrometry (MS) has proven capable of producing complicated spectral signatures from biological materials within seconds. This positions MS as a core technology for meeting the challenge of bio-aerosol detection with adequate differentiation of detected agents. This chapter gives an overview of several lines of MS technology development and of the current state-of-theart in real-time bio-aerosol MS. After the previous two decades of early technology development, the next five years will see the evolution of mature MS-based bio-aerosol detection.

Arjan L. van Wuijckhuijse and Ben L.M. van Baar - TNO Defence, Security and Safety, Rijswijk, the Netherlands.

M. Zourob et al. (eds.), Principles of Bacterial Detection: Biosensors, Recognition Receptors and Microsystems, (C) Springer Science+Business Media, LLC 2008 


\subsection{Scope}

This chapter covers the MS of aerosols, in a broad sense, with a focus on the mass spectrometry of bio-aerosols, particularly of bacteria. Viruses and other agents are not considered, mainly because there are hardly any published reports on bio-aerosol MS of such agents. This section of the introduction deals with two lines of approach: MS of bacteria and MS of aerosols, in respective subsections. The next section discusses the current state of technology of bio-aerosol MS, after a brief introduction that ties MS of bacteria to MS of aerosols. The chapter concludes with a section on the outlook, focusing on the development of fieldable bio-aerosol mass spectrometers.

\subsection{MS in the Whole Cell Analysis of Bacteria}

Nowadays, several forms of MS are widely employed in the typing of bacteria. The information gained by MS can range from the profiling of intact cells to the detail of proteomics or nucleotide sequencing. However, chemical analysis by MS is an emerging method with respect to established microbiological typing methods, like serotyping, microscopy, and phage typing. Where identity of organisms is discussed between analytical chemists and microbiologists, misunderstanding often arises from a difference in perception of "identity" between the two disciplines. This issue is briefly addressed in the first subsection, to clarify the point that the many approaches to the identification of bacteria correspond to various levels of certainty. The second subsection gives a brief, non-exhaustive overview of applications of MS to the analysis of whole cell material from bacteria, with emphasis on aspects of potential screening and detection technology.

\subsubsection{The Definition of 'Identity' of Bacteria}

The understanding of "identity" in microbiology differs considerably from that of chemistry. In chemistry, identity is assigned on the basis of comparison of molecular structure, for example by spectroscopic methods. Although we like to think that live material is also subject to the rigidity of molecular structure, the adaptive and evolutionary qualities of life imply a certain fuzziness in chemical composition. Historically, classical microbiology and bacteriology set out to assign microorganism identity by descriptive comparison of a selected set of observable characteristics. These characteristics would be morphological, for example colony shape in culturing or cell shape in microscopy. Later methods of typing employed indirectly observable characteristics, for example particular enzymatic activity, chemical resistance or affinity, or immunological activity. With the advent of chemical methods of analysis, typing would also address parts of the chemical composition of microorganisms, like fatty acid distribution or excreted metabolites. The molecular biology revolution, which started around 1980, has provided typing methods based on hereditary properties as these are addressed through the analysis of DNA. It is envisaged that molecular biology may provide a Grand Unification Theory for typing of microorganisms. That will also resolve the practical problem of the evolution of "standards" because the abstract information can be documented on paper rather than in a collection of organisms. However, where the link between DNA sequence and biological function is still largely elusive, molecular biology cannot yet accomplish unification by the incorporation of existing typing schemes.

Without that Grand Unification scheme accomplished or even partly available, every bacterial typing method occupies its own dimension (see, for example, Spiegelman, Whissell, and Greer 2005). Studies employing multiple typing methods provide a link between the separate dimensions, often on an empirical basis. For example, if a bacteriophage susceptibility profile is obtained from a specifically serotyped Salmonella isolate, a single mapping term 


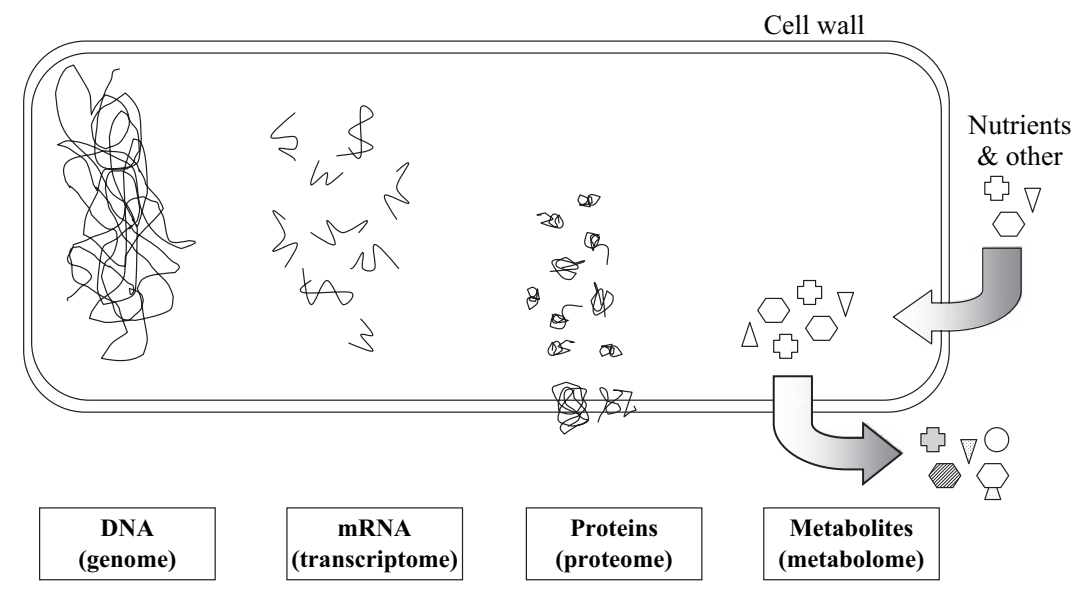

Figure 36.1. Representation of the distance of information from bacterial characteristics relative to the information in the genome.

is established between bacteriophage typing and serotyping. If mapping from a given typing method to other typing methods is not available, that typing method remains subjective. For practical purposes, for example in epidemiological comparison of bacterial strains from an outbreak, that subjectivity may be sufficient. When the identification problem is limited to a "threat list," subjectivity will be insufficient. Even when the typing profiles of all organisms on the "threat list" are acquired, it remains to be proven that no organisms on the list give the profile of one of the threat agents. For typing in any environment, a link to objective information, generally a DNA sequence, is eventually required to overcome the typing method dimension problem.

As MS methods for the typing of bacteria are concerned, the distance to the objective information of genomic DNA can be qualitatively evaluated. Fig. 36.1 gives the relative information distance of several characteristics of bacteria as they are accessible by chemical analysis.

\subsubsection{Mass Spectrometry of Bacteria}

Mass spectrometry is currently widely employed in the analysis of bacteria or their constituent compounds (as reviewed, see Van Baar 2000; Fenselau and Demirev 2001; Lay 2001; Fox 2006). However, many of the laboratory methods are not suitable for the detection of aerosolized bacteria, because sample treatment is too elaborate. Therefore, analysis of whole cells with little or no sample treatment is the only option, with the process applied to bulk material or to single cells in single particles. This subsection gives an overview of whole cell MS of bacteria, with emphasis on the signature obtained.

\subsubsection{Pyrolysis $M S$}

Early studies typically employed the mixture analysis capabilities of the then-newly emerging GC-MS technology, in pyGC-MS (Simmonds, Shulman, and Stembridge 1969; Simmonds 1970). A transition to direct inlet pyMS was quickly made for detection purposes because GC separation is relatively time consuming (Meuzelaar and Kistemaker 1973). Also, the use of field ionization (FI) (Schulten et al. 1973), chemical ionization (CI; Van der Greef, Tas, and Ten Noever de Brauw 1988), and metastable atom bomdardment (MAB; Wilkes et al. 2005) with pyMS was explored as an alternative to common electron ionization (EI). 
Other studies addressed spectral comparison, for example through multivariate methods (Shute et al. 1984), artificial neural networks (Freeman, Sisson, and Ward 1995), or genetic algorithms (Taylor et al. 1998). PyMS was successfully applied in the differentiation of pathogens within specific families of bacteria, for example Mycobacteria (Wieten et al. 198) and Salmonellae (Van der Greef, Tas, and Ten Noever de Brauw 1988; Wilkes et al. 2005). Even though specific compounds were identified as pattern markers (e.g., DeLuca, Sarver, and Voorhees 1992), identification has always remained confined to a "fingerprinting" approach requiring the availability of a library or of a basis set of qualified spectra. Therefore, pyMS of bacteria is still typically used for quick screening, for example of clinical samples (Kyne et al. 1998; McCracken et al. 2000) or mail (Wilkes et al. 2006).

For many purposes, comparative matching of spectra or profiles is unsatisfactory because it does not allow a translation to other and independent knowledge available on the biological material at hand. For bacteria, this problem was approached by the application of MS/MS or by a minimum sample pretreatment. An example characteristic accessible by MS/MS is dipicolinic acid (DPA). This compound makes up 5-15\% of a Bacillus spore, and as such it is representative for the possible presence of Bacillus anthracis. Specific pyMS based methods for detecting Bacillus through DPA were developed (Beverly et al. 1996; Goodacre et al. 2000; Tripathi, Maswadeh, and Snyder 2001). Tandem mass spectrometry was employed to show that a more general characteristic of bacteria, their fatty acid profile, is accessible by pyMS/MS without prior chromatographic separation (DeLuca et al. 1990). A fast in situ chemical methylation reaction, to form fatty acid methyl esters (FAMEs), is included to allow better volatilization (Basile et al. 1998; Barshick, Wolf, and Vass 1999; Tripathi, Maswadeh, and Snyder 2001; Poerschmann et al. 2005). Although FAME profiling does not provide a complete typing scheme for bacteria, correlation with laboratory profiles can be employed in detection applications. Thus, the targeting of specific components by pyMS through MS/MS or fast in situ sample treatment obviates the need for elaborate full spectrum matching in detection.

\subsubsection{2. $L D I M S$}

LDI or LAMMA have not found much application in the typing of bacteria. The elemental analysis capability of LAMMA was employed to measure the $\mathrm{Na}^{+} / \mathrm{K}^{+}$ratio in individual cells in order to establish the live or death status of Mycobacteria in response to external factors (Seydel et al. 1982; Seydel and Lindner 1988). Böhm et al. (1985) demonstrated laser ionisation of single bacterial cells from three Bacillus species. They concluded that high laser power densities $\left(>1000 \mathrm{Wcm}^{-2}\right)$ were required to obtain positive or negative ions in pyMS-like spectra (see Fig. 36.2).

A discriminant analysis showed that typing by classification was poor, 70 to $75 \%$, even with this small Bacillus training set (Böhm et al. 1985). One later study, which compared several desorption/ionization methods in the analysis of cells, showed that the type of laser ionization employed in LDI and LAMMA gave signals of intact polar lipids from lysed E. coli (Heller et al. 1987). From these pioneering studies it is clear that LDI and LAMMA do not provide a sound basis for bacteria typing, because typing information is at best highly convoluted and of poorer quality than the information obtained from pyMS. In addition, the first reports on application of MALDI MS to bacteria, in the mid 1990s, left LDI and LAMMA obsolete as far as bacteria typing was concerned.

\subsubsection{MALDI MS}

Three pioneering studies on MALDI MS of vegetative whole bacteria were published independently in 1996 (Holland et al. 1996; Claydon et al. 1996; Krishnamurthy and Ross 

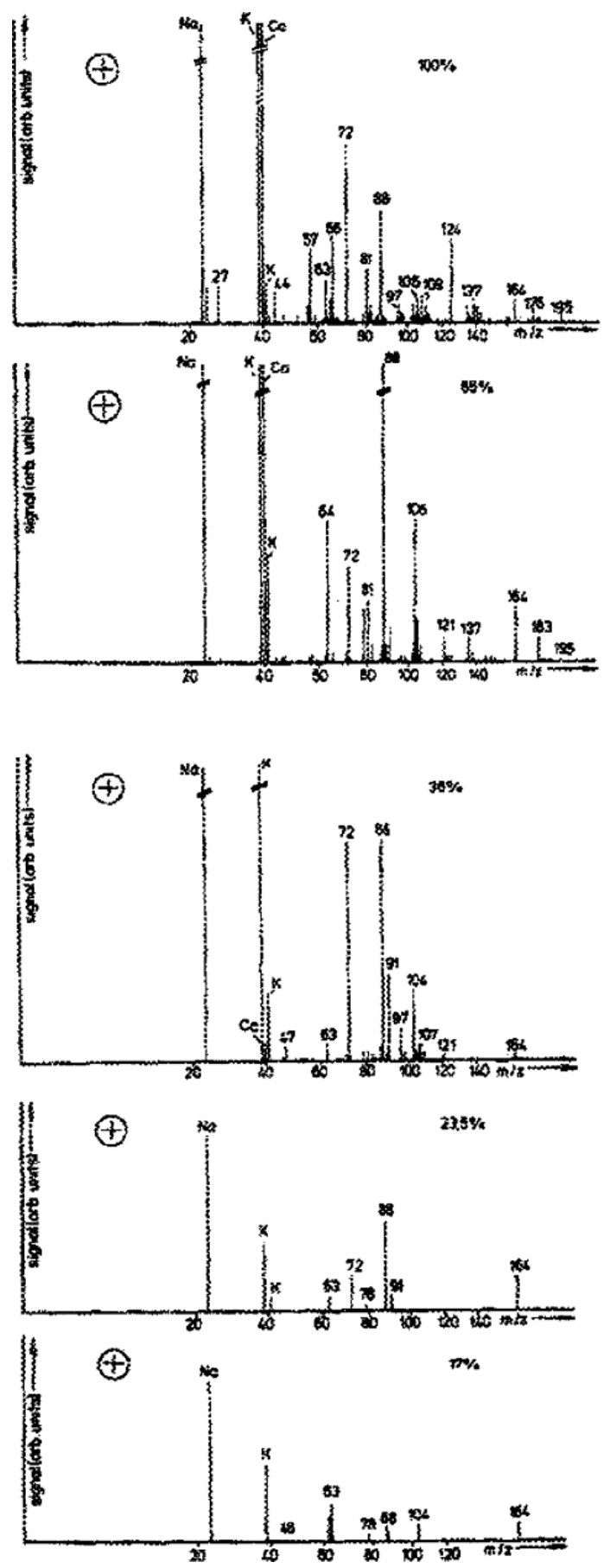

Figure 36.2. Typical LAMMA mass spectra of Bacillus cereus from pioloform foil with a copper grid, at a laser power density of $85 \%$ (top) and $35 \%$ (bottom) of the full Nd:YAG laser power (reprinted from Böhm et al. (1985), with permission of Elsevier). 


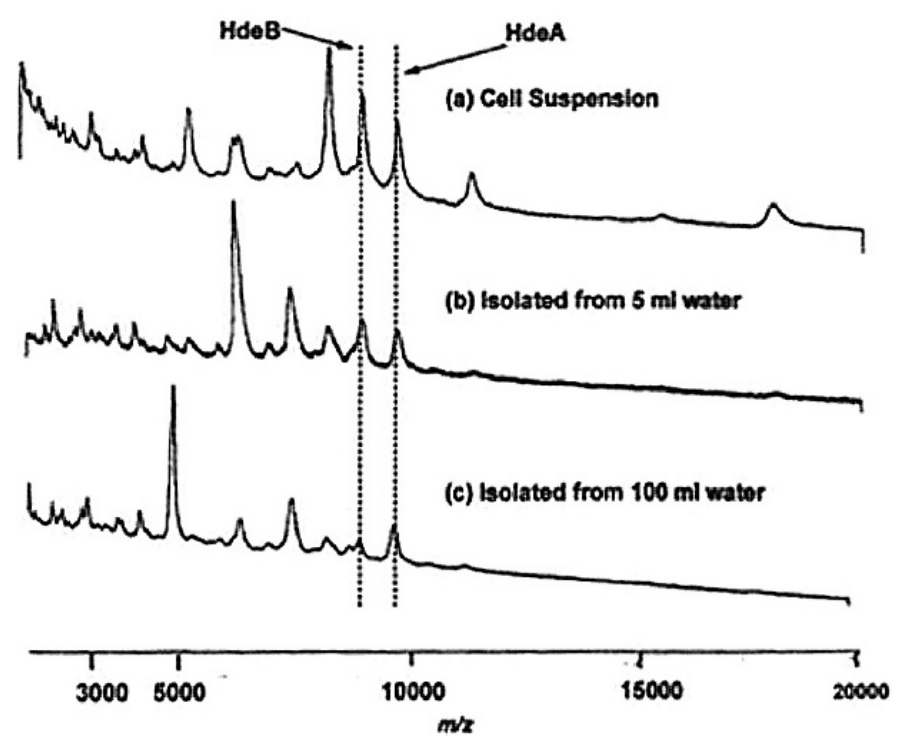

Figure 36.3. Typical MALDI mass spectra of Shigella flexneri with indication of the HdeA and HdeB protein signals (Reproduced from Holland et al. 2000, @John wiley \& Sons Limited).

1996). Three different sets of bacteria were employed in the three studies to arrive at a similar conclusion: Specific biomarker signals were repeatedly observed in the mass spectral profiles. Moreover, these signals allowed typing of the bacteria, at genus, species and strain level, by comparison to earlier recorded spectra or to newly acquired spectra from freshly cultured strains (see Fig. 36.3). Although these three studies used different mass ranges and different methods for sample application to the MALDI target, the work established a starting point for later studies.

The robustness of whole cell MALDI MS of bacteria was tested in many studies, which all show that sample preparation and details of the ionization process are important parameters for experimental control (e.g., Wang et al. 1998; Evason, Claydon, and Gordon 2001; Saenz et al. 2001; Williams et al. 2003). Bacterial growth conditions are beyond experimental control, at least in a real detection environment, but their effect on the variability of spectra has triggered further study. For example, it was observed that number and intensity of peaks varied considerably among spectra when E. coli $\mathrm{K} 12$ bacteria were sampled at selected stages between 6 to $84 \mathrm{~h}$ after inoculation of a culture (Arnold et al. 1999). However, the general trend is that protein fingerprinting in whole cell MALDI provides adequate identification despite the innate variability (e.g., Valentine et al. 2005; Wunschel et al. 2005a). Several studies with a wide scope have been reported, for example an interlaboratory study (Wunschel et al. 2005b) and some large scale typing studies for food pathogens (Mandrell et al. 2005), clinical isolates (Nilsson 1999; Marvin, Roberts, and Fay 2003; Keys et al. 2004), and in biotechnology (Jones et al. 2005).

Data analysis is an important and yet unsettled issue in whole cell MALDI MS. Most of the data analysis research focuses on the processing of spectra as "fingerprints." Because similar fingerprint type processing is also used in pyMS, procedures can be adapted for the purpose. However, plain spectrum fingerprint matching discards the more hidden information from the bacterial genome. The observed high-mass signals, over $1000 \mathrm{Da}$, are generally taken to represent peptides and proteins of which the mass is determined by the amino acid sequence. Therefore, these signals are considered "biomarkers" of the investigated bacteria. The biomarker link to genomes provides a more objective kind of information (Demirev et al. 1999), from a sequence database that is essentially independent of any analytical method. The notion of biomarkers implies that there is a potential for the kind of spectrum prediction that obviates the need for library accumulation. At present, fingerprinting is the established way for bacteria 
typing by MALDI MS, and the link to genome information is still under investigation. Both approaches are briefly discussed below.

Fingerprints may be accumulated as an internally consistent set, while the actual spectra are machine-dependent and sample dependent. Raw spectra are rarely used as fingerprints, and several condensation methods have been reported, for example cross-correlation (Arnold and Reilly 1998) and extraction of numerical fingerprints (Jarman et al. 1999; Jarman et al. 2000). Actual spectrum comparison is then achieved by methods also employed in matching of pyMS spectra, for example in the neural network approach demonstrated with SELDI (Schmid et al. 2005). The accumulation of a well-defined set of library spectra, possibly in a condensed form, is an elaborate job. However, it is generally assumed that translation of fingerprint data to other instruments and conditions is possible. This assumption was studied in an objective way by consideration of the protein distribution against the significance of an identification, for a limited set of organisms (Pineda et al. 2000). It was concluded that the cluttered and incomplete nature of the spectral data, as compared to bacterial proteomes, complicates or even compromises truly robust identification. At a practical level, the assumption of cross-instrument translation is supported by a single published interlaboratory study, which showed that tight control of sample treatment and of instrument conditions allows translation of MALDI MS fingerprints between instruments (Wunschel et al. 2005b). The assumption is further corroborated by the development of two commercially available MALDI MS platforms with libraries for bacteria typing: from Waters (employed, e.g., by Keys et al. 2004) and from Bruker (employed, e.g., by Maier et al. 2006). Although theoretical considerations and practical experience have not yet fully resolved the issue of method robustness, bacterial fingerprinting has become fairly well established as a method for bacteria typing in a laboratory setting and with a certain level of prior knowledge about target bacteria, for example in the screening for dairy pathogens.

Although the word biomarker appears in the pioneering papers on whole cell MALDI MS of bacteria, the link of signals to actually identified bacterial proteins was fairly speculative or even absent. Later studies provided more substantial evidence, for example for the identity of certain proteins from Bacillus spores (Hathout et al. 1999) or independent proof of protein identity for specific MALDI MS signals (e.g., Hathout et al. 2003; Dickinson et al. 2004). On the basis of this sporadic approach it was proposed by the group of Fenselau that it would be most likely that basic proteins, like many of the ribosomal proteins, are responsible for biomarker signals (Pineda et al. 2003). The proposal was corroborated by experiments that showed it is tenable as a working hypothesis, provided that post-translational modification of the proteins is accounted for (Demirev et al. 2001). Although this working hypothesis does not have any absolute predictive value, the basic protein approach is the most generalized proposal for biomarker attribution to date.

\subsubsection{Comparison of MS Methods for Whole Cell Bacteria Typing}

PyMS, LDI MS and MALDI MS have proven useful in rapid typing of bacteria in the laboratory, for which purpose they are operated with bulk samples and in a batchwise fashion. No direct experimental comparison of these methods is available. In addition, differences in ionization, in the bacterial compounds addressed, and in possible sample treatment hamper a theoretical comparison, for example of the sensitivity. For a qualitative consideration, a comparison can be made of the capability for generic bacteria typing to the attainable degree of resolution in typing (to the increasingly more detailed levels of bacteria/non-bacteria, bacteria genus, species, strain, and isolate).

PyMS, as it is applied in rapid analysis, will give information about the presence of a Bacillus genus marker (DPA), or it will produce a FAME profile. As a Bacillus detector, pyMS is not generic, and it has no further degree of typing resolution. From laboratory studies of FAME profiling without pyMS but by plain GC or GC-MS (e.g., Abel, DeSchmertzing, and 
Peterson 1963; Moss 1990), it is clear that typing resolution may be highly specific within certain families of bacteria and fairly unspecific in other families. In addition, FAME profiles are known to change with changing environmental conditions, such as bacterial nutrition (see, e.g., Stoakes et al. 1991). As a FAME profiler, pyMS is a generic method, because such a profile can be generated from any bacteria. Overall, pyMS does cover some of the needs for rapid typing in the laboratory, while the method seems to have reached its full potential.

LDI MS and LAMMA, as they can be applied in rapid analysis, will not give very distinctive information. The near-atomization conditions of the direct laser ionization destroy the structure of biological compounds to an extent that highly specific molecular information is not observed. No recent reports have appeared on LDI MS or LAMMA investigations of bacteria in the laboratory. For laboratory typing of bacteria, LDI MS and LAMMA have been surpassed by MALDI MS at the present state of technology.

MALDI MS, as it is applied in rapid whole-cell analysis, will produce a biomarker profile in a single mass spectrum. Because this procedure can be done with any bacteria, the method is generic. Opinions on the specificity and usefulness of such a profile have come to some consensus with an increasing number of studies becoming available. The general conviction (see, e.g., Lay 2000) is that certain true biomarkers will always be present, whereas other biomarker signals will show major variations with environmental conditions such as culturing or growth stage. The principal advantage that biological molecules stay intact in MALDI, to retain the information content, is hardly employed, because most studies use plain profile matching. Overall, MALDI MS is well suitable to rapid typing of bacteria in the laboratory, while the method requires further exploration to assess its full potential.

\subsection{Aerosol MS}

MS analysis of aerosols can be accomplished in many ways. Some of the typical laboratory MS methods have been adapted to allow analysis of deposited aerosols, with sampling and chemical analysis offline. In addition, dedicated aerosol MS analysis technology was developed, to allow direct analysis of single particles from atmospheric aerosols without sample deposition. Although the deposition and direct analysis type methods share some of the technology, they are discussed separately.

\subsubsection{MS of Deposited Aerosols}

Bio-aerosols are often made amenable to mass spectrometry by particle collection. Although particle collection will allow further preparation for any desired MS analysis, subsequent sample treatment is generally minimized to allow quick analysis. Currently, one of three modes of MS analysis is typically employed: pyrolysis with EI or CI, laser desorption/ionization (LDI), and matrix-assisted LDI (MALDI). Because these modes of analysis produce distinct information from biological material, they are briefly discussed.

\subsubsection{Pyrolysis $M S$}

Pyrolysis generates volatile compounds from biological material, both by evaporation of any volatile compounds present and by the formation of new volatile compounds in elimination reactions under the influence of heat. The pyrolysis process can be conducted in a classical MS source to allow subsequent ionization. Many mass spectra can be acquired during a pyrolysis cycle to give a time-resolved profile. The spectra, the profile, or both can be employed as a characteristic for that particular biological material.

Pyrolysis MS (pyMS) initially evolved as a method for the chemical analysis of bacteria after it had been shown in the 1960s that pyrolysis gas chromatography (pyGC) provided 
"fingerprinting" of bacteria (see, e.g., Oyama 1963; Reiner 1965; Stern, Kotula, and Pierson 1979). Therefore, pyMS of bio-aerosols is discussed in more detail in the next section.

\subsubsection{LDI MS}

Laser desorption/ionisation (LDI) was developed in the late 1970s and early 1980s (e.g., Hillenkamp et al. 1975; Stoll and Röllgen 1979; Cotter 1980), when suitable laser technology became available. LDI was typically used for samples applied to a surface, and to direct surface analysis. In LDI, the ionizing laser energy is dissipated by the sample material and the corresponding energy density is generally so high that covalent chemical bonds easily dissociate. This laser ablation process burns away minute amounts of sample material. Therefore, a laser desorption spectrum will generally show signals of native ions such as $\mathrm{Na}^{+}$and $\mathrm{NO}_{3}^{-}$, and of atomic cluster ions such as $\mathrm{C}_{3}^{+}$and $\mathrm{C}_{3} \mathrm{H}^{-}$, formed from the organic or biological compounds present. A typical example of such a spectrum is shown in Fig. 36.4. The high energy density in LDI makes the method less suitable for the ionization of relatively thermolabile organic and biochemical compounds. Nevertheless, occasional reports of successful LDI analysis of such compounds have appeared (see, for example, Balasanmugam et al. 1986; Posthumus et al. 1978). In many cases, the ionization of such thermolabile compounds involved preformed cationized and anionized species (Cotter 1981; Balasanmugam et al. 1981; Zakett et al. 1981).

The utility of LDI was greatly enhanced by combining the ionization with microscopic accuracy control of the ablation position to within $1 \mu \mathrm{m}$ resolution (Hillenkamp et al. 1975; Wechsung et al. 1978). That form of LDI, generally known as Laser Ablation Microprobe Mass Analysis (LAMMA), was typically used for the analysis of samples on a surface. Initially, the capability for analysis of deposited aerosol particles was oddly reported among biomedical applications (Kaufman, Hillenkamp, and Wechsung 1979), but LAMMA was then quickly adopted by aerosol investigators (Wieser, Wurster, and Seiler 1988). The initial studies concerned technology development, for example for measuring the elemental composition of micron size particles (e.g., Bruynseels and Van Grieken 1984). This technology was then applied in atmospheric aerosol research (e.g., Bruynseels et al. 1988; Dierck et al. 1992; Hara et al. 1996). These aerosol studies generally encompassed inorganic analysis, where the particle

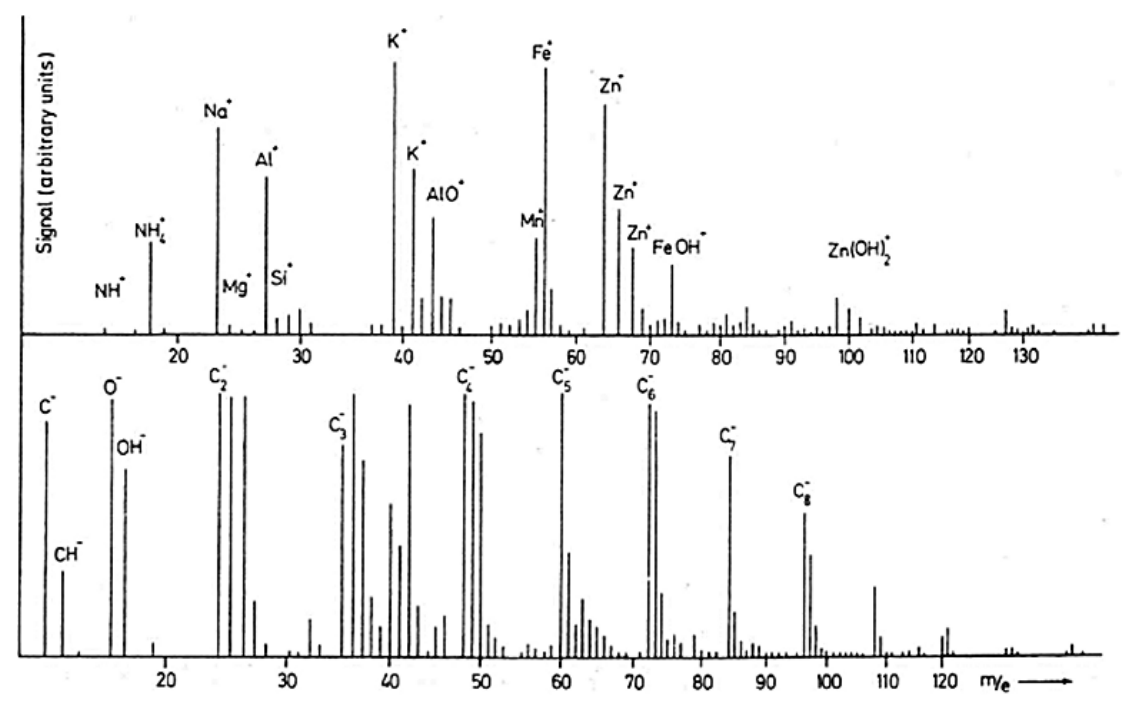

Figure 36.4. Negative ion (top) and positive ion (bottom) aerosol LDI spectra obtained from giant aerosol particles (reprinted from Wieser et al. (1980), with permission of Elsevier). 
size range investigated was set by the aerosol fraction trapped by the offline sampler. In these studies, LAMMA MS is typically used for the analysis of the low $Z$ elements, such as $\mathrm{C}, \mathrm{N}$, and S. Other methods, like electron probe X-ray microanalysis (EPXMA), turned out to be more suitable for the higher $Z$-elements, such as heavy metals (e.g., Van Malderen, Hoornaert, and Van Grieken 1996). Although only a single LAMMA study was reported in recent years, the available aerosol sampling technology and offline LAMMA analysis in a remote laboratory provided many new insights in environmental aerosol chemistry.

\subsubsection{MALDI MS}

MALDI MS evolved from LDI in the late 1980s (Tanaka et al. 1987; Karas and Hillenkamp 1988), when it turned out that the application of a specific "matrix" compound with a sample produced high mass ions upon UV laser irradiation. The matrix is thought to dissipate most of the incident UV energy. The matrix is also supposed to be a proton donor in positive ionization, and a proton acceptor in negative ionization. Although several studies were devoted to elucidation of the details of the MALDI ionization process (see, e.g., Knochenmuss and Zenobi 2003; Karas and Krüger 2003), there is no consensus theory or model. As a consequence, much of the chemistry involved in MALDI is still empirical.

The persistence of the empirical experimental component has not kept MALDI from gaining enormous acclaim as a method for MS of biological compounds. Empirical studies in MALDI MS covered issues like matrix crystallization (e.g., Westman et al. 1995; Dai, Whittal, and Li 1996; Luxembourg et al. 2003) and sample desalination (e.g., Kussman et al. 1997), to set the standard for a plethora of applied studies of large molecules in polymer science (e.g., Nielen 1999; Macha and Limbach 2002), microbiology (viruses, e.g., Lewis et al. 1998; Fenselau and Demirev, 2001; for bacteria, see above), and direct tissue analysis and imaging (e.g., Stoeckli, Farmer, and Caprioli 1999; Schwartz, Reyzer, and Caprioli 2003; Altelaar et al. 2005). MALDI MS also found application in aerosol analysis, as will be discussed later on.

For the purpose of this overview, surface enhanced laser desorption/ionization (SELDI) should also be included. SELDI was developed as a combination of MALDI with affinity capture chip technology on the target (Hutchens and Yip 1993; Caputo, Moharram, and Martin 2003). SELDI is the sophisticated, often commercialized variant of earlier academic experiments with on-target sample preparation (e.g., Brockman and Orlando 1995; Liang et al. 1998; Bundy and Fenselau 1999) for MALDI. The SELDI chip that serves as the laser target is coated with specific affinity molecules to allow on-target cleanup before matrix application and actual MS. Mass spectra are then obtained from any material retained by the affinity surface, for a rapid characterization of target material captured from the original sample. The chip technology makes SELDI particularly useful for quick screening of large amounts of samples, for example in clinical diagnosis of cancer by biomarkers (recently reviewed in Engwegen et al. 2006) and for bacteria typing (e.g. Schmid et al. 2005; Al Dahouk et al. 2006).

\subsubsection{Direct MS of aerosols}

In the 1980s LDI MS and LAMMA were proven to be of use in atmospheric (bio-)aerosol research. However, the required particle collection provided a cross-section picture of a certain particle size class, but any particle concentration information got lost in the process. In a separate development, Sinha et al. constructed an aerosol mass spectrometer for the analysis of individual particles. A beam of particles was continuously fed into the source of a quadrupole (Q) mass spectrometer, with in-source pyrolysis by a heated filament and electron ionization (Sinha et al. 1985). A key problem is that Q type mass analyzers require a constant ion input for a time span in the order of one second during a full mass range scan, whereas single particle 

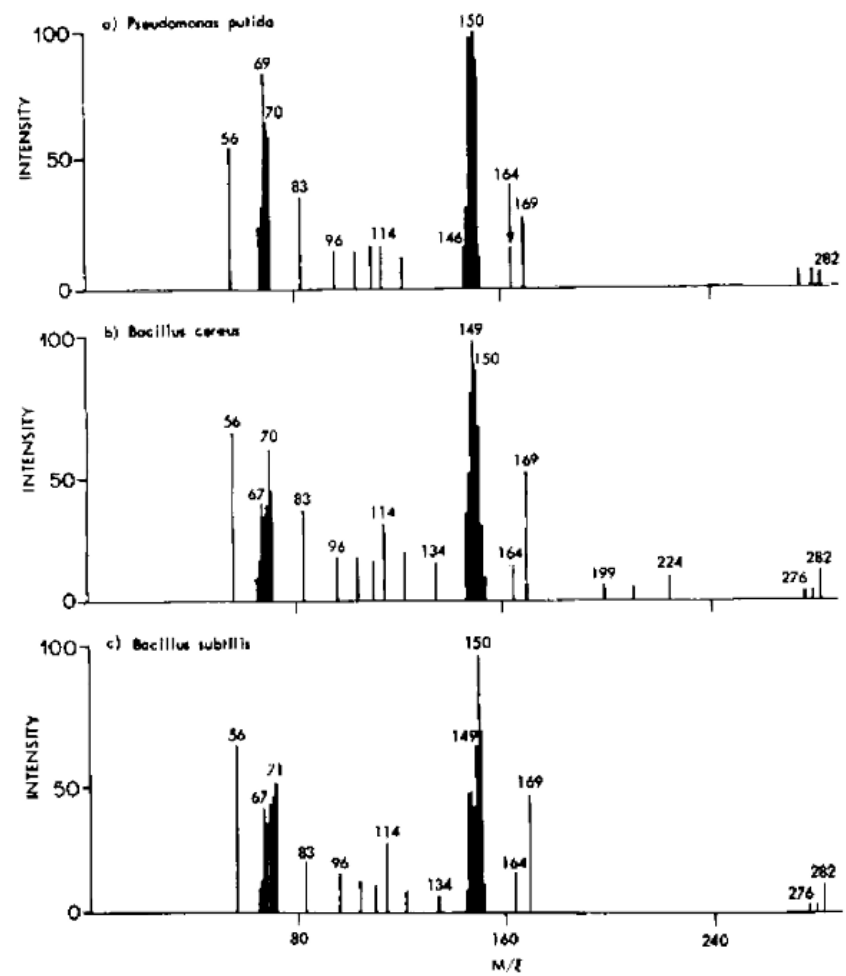

Figure 36.5. PyMS mass spectra of bacteria particles, Pseudomonas putida (top), B. cereus (middle), and B. subtilis, obtained with a particle beam quadrupole mass spectrometer (from Sinha et al. 1985; reproduced by permission of the American Society for Microbiology).

ionization produces only a short burst of ions during a period in the order of a millisecond. This problem was resolved by using the Q mass spectrometer as a band pass filter at a width of a few mass units. By stepping through multiple bands the 40-300 Da mass range was covered. This yielded mass spectra from a bacteria aerosol (Fig. 36.5), where a single spectrum would have required ionization of over $10^{5}$ bacteria containing particles. This kind of sensitivity and mass range are not practically useful, but the work provided a most important proof of principle.

The concepts of the use of laser ionization (Sinha 1984) and of the use of time-of-flight (TOF) instead of Q mass spectrometers (Marijnissen, Scarlett, and Verheijen 1988) for single particle analysis were clear by the mid 1980s. However, the actual hardware development took until the early 1990s, when suitable lasers and mass spectrometers had finally become available. The technology was discussed in several reviews (Suess and Prather 1999; Noble and Prather 2000; Murphy 2006) and a summary description is given in the next section before the current state of the technology is addressed.

\section{Current State of the Technology}

\subsection{Considerations on Aerosol MS of Bacteria}

From the technology for aerosol MS and the application of MS to non-aerosolized bacteria it follows that the routine use of aerosol MS for the detection of bacteria is within reach of 
technology. It is also clear that the development and performance of such bio-aerosol MS technology is determined by several issues:

- aerosol deposition versus direct aerosol analysis;

- the possibility of applying any degree of sample treatment in the analysis process, either to single particles in the aerosol phase or after aerosol deposition;

- access to genome or proteome linked information versus accumulation of fingerprint type information.

At present, the field of bio-aerosol MS encompasses a variety of technology solutions, each of which deal with the above issues in their own way. This section discusses the available technology, as it was developed by the various research groups, with a clustering of similar technology.

\subsection{Deposition and PyMS Based Technology}

Pyrolysis MS based technology for the detection of bio-aerosols is currently best developed. PyMS analysis implies deposition of aerosol particles in a bulk, which process makes the particulate matter amenable to any form of elaborate sample treatment prior to the actual MS analysis (e.g., Szponar and Larsson 2001). However, because time is of the essence in bio-aerosol detection, two rapid methods with minimum sample treatment have found their way to field application: DPA confirmation and in situ derivatization with FAME profiling.

The proved presence of DPA in spores of the Bacillus family (see above) opened the way to a detection method for Bacillus anthracis, a main threat agent. Pyrolytic liberation of the acid and subsequent MS/MS in an ion-trap type instrument formed the key "biological" capability in the first version of the "Chemical and Biological Mass Spectrometer" detector (CBMS). The in situ methylation used for FAME profiling also methylates DPA. Thus, detection of dimethyl-DPA is still a key feature of the second version of the CBMS detector, the CBMS Block II (Hart et al. 2000; Lammert et al. 2002; see Fig. 36.6). Although the scope of DPA detection is limited to Bacillus species, it presently supports the only operational detector with a capability to differentiate to the level of an anthrax or closely related threat.

The development of a rapid process for in situ methylation, by heating with tetramethylhydroxide (TMH), formed the basis for FAME profiling in a field setting. This required some
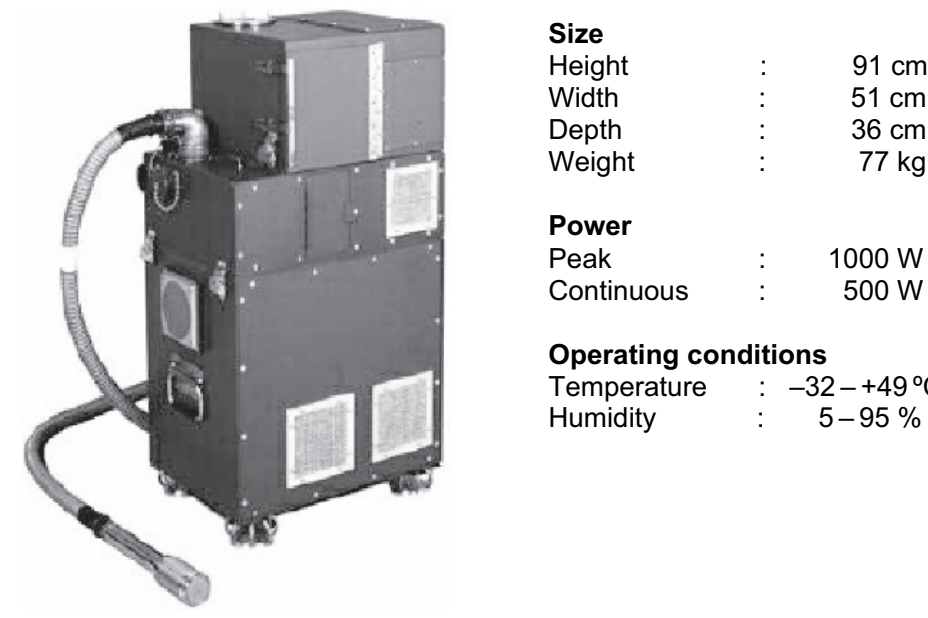

\section{Operating conditions}

Temperature : $-32-+49^{\circ} \mathrm{C}$

Humidity : $\quad 5-95 \%$

Figure 36.6. Example of fieldable pyMS based equipment: the CBMS Block II instrument. 
instrument and process optimization to allow sequential TMH treatment and pyrolysis in a single reaction vessel and to allow batchwise sample introduction. Several potentially transportable MS based detector systems have been under investigation for FAME profiling (e.g., Hart et al. 1999; Gardner et al. 2005), and the method has become the key mode of "biological detection" in the second version of the CBMS detector (Hart et al. 2000; Lammert et al. 2002). Some validation studies of the CBMS Block II system have appeared, to demonstrate much of its capabilities (e.g., Luo et al. 1999; Griest et al. 2001). For bacteria and fungi, the CBMS is presently the single operational biological detection system with a differentiation capability to the genus level and, sometimes, to the species level.

\subsection{Deposition and MALDI MS Based Technology}

The sample preparation process for on-target MALDI does not lend itself to easy automation in a batchwise process. To our knowledge, there is only a single line of development based on off-line aerosol entrapment and subsequent MALDI MS. In the mid 1990s it was demonstrated that a TOF mass spectrometer with a flight tube of a few centimeters long can have the performance of an instrument with a flight tube of over 1 meter in length (Cornish and Cotter 1992; Bryden et al. 1995). This small TOF mass spectrometer was the basis for interfacing with aerosol sampling and MALDI, as it was developed at the Johns Hopkins University Applied Physics Laboratory (JHU-APL) and described in a patent (Anderson and Carlson 1999; Anderson et al. 2003). Typically, aerosol is sampled onto a tape by an aerosol sample collector, where the sampling determines the overall duty cycle for detection. After completion of a sampling/deposition cycle, a matrix is applied and the tape is interfaced with the mass spectrometer by a sealable opening. With the sample spot on the tape in the correct position inside the mass spectrometer source, a common MALDI MS experiment can be conducted. Investigations on the performance of this system were not published in peerreviewed journals, but aspects of system development were covered in JHU publications (e.g., Antoine et al. 2004). Although it is hardly possible to come to an evaluation of sensitivity and performance of this aerosol MALDI TOF MS system on the basis of the scant literature data, it is obvious that the technology has the full potential of MALDI MS for the identification of bacteria.

\subsection{Single Particle LDI MS Technology}

Following the pioneering work of Sinha (1984; Sinha et al. 1985) and a first concept of a single particle aerosol mass spectrometer (Marijnissen, Scarlett, and Verheijen 1988), first reports of actually built instruments appeared in the early 1990s (McKeown, Johnston, and Murphy 1991; Kievit et al. 1992). A typical design for a single particle MS instrument is given in Fig. 36.7 (Van Wuijckhuijse et al. 1998). Environmental aerosol is sampled into the mass spectrometer vacuum through a differentially pumped beam generator. The emerging particle beam is made to pass a low power continuous wave laser beam, where every single particle gives light scattering. The scattered light is detected and employed to fire a high power pulsed excimer UV laser, in order to ionize the particulate material. As the ionization events are located in the source of a TOF mass spectrometer, the ionization laser shot is also used to mark the start of the TOF MS process. Because this experimental set-up only allowed analysis of particles with a certain pre-set size, the demonstrator instruments served as a starting point for further exploration, pursued by several research groups.

The integration of aerodynamic sizing with triggering of the ionization laser, in a threebeam laser arrangement, made particle analysis more versatile (Weiss et al. 1993; Prather, Nordmeyer, and Salt 1994; Carson et al. 1995; Kievit et al. 1996). A double low power 


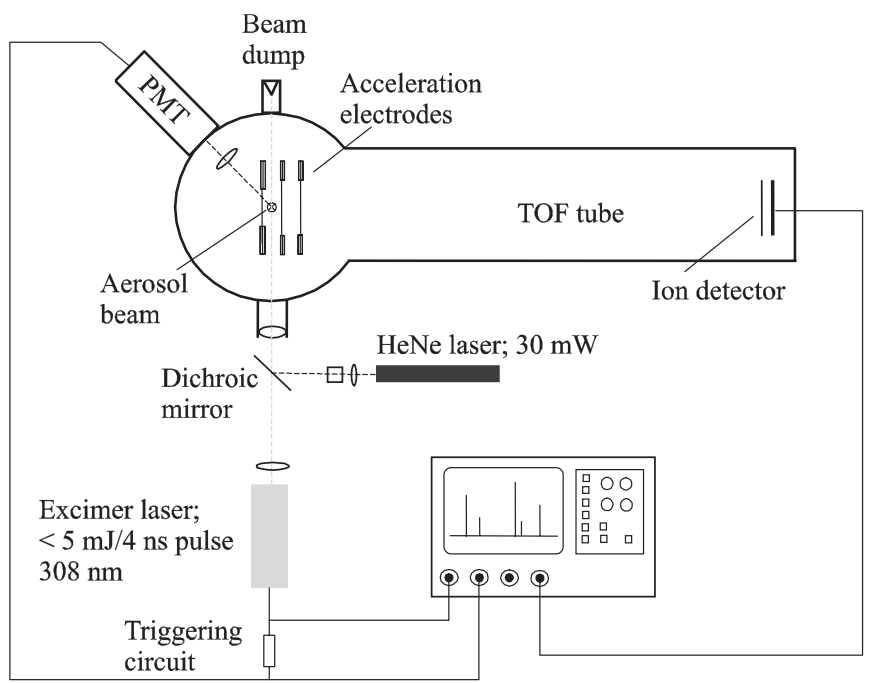

Figure 36.7. Typical design layout of a single particle aerosol MS instrument.

laser beam passage made ionization laser triggering a size independent process, and particle beam generation now became the main determinant for the particle size range. In addition, synchronous positive and negative ion TOF MS was implemented to improve detection capability (Hinz, Kaufmann, and Spengler 1994). Redesign to a transportable instrument was investigated (Gard et al. 1997). Also, the use of Ion Trap MS, instead of TOF MS, was explored (Dale et al. 1994; Yang et al. 1995). Finally, the TOF based technology was developed into a commercial instrument for the analysis of chemical aerosols (TSI Inc., USA; www.tsi.com).

Recently, it was shown that the same technology can be applied in the analysis of single particles of a bio-aerosol composed of Bacillus spores or Mycobacteria (Steele et al. 2003; Fergenson et al. 2004; see Fig. 36.8). Ionization was accomplished with the help of a $266 \mathrm{~nm}$ pulsed UV laser, for which it was considered that $266 \mathrm{~nm}$ coincides with the UV absorption maximum of the dipicolinic acid that is abundant in such spores. In a later study it was shown that the fluence threshold and the beam profile of the ionization laser are of prime importance to the spectrum quality and abundance (Steele et al. 2005). Data analysis in the Bacillus study showed that $\mathrm{m} / \mathrm{z} 74^{+}$and $\mathrm{m} / \mathrm{z} 173^{-}$ions provided the main discriminant signals, where the positive ions were proposed to originate from trimethylglycine (Srivastava et al. 2005) and the negative ions from free arginine (Fergenson et al. 2004). However the robustness of these marker signals turned out to depend on the micro-organism growth conditions: Different growth conditions lowered the probability of detection of B. atropheus from 93 to $73 \%$, whereas the distinction from B. thuringiensis was lost (Fergenson et al. 2004). Specifically for B. atropheus, the impact of growth on the particle mass spectrum was investigated in more depth (Tobias et al. 2006). It was also shown that Mycobacterium tuberculosis can be distinguished from Bacillus cereus, B. atropheus, and Mycobacterium smegmatis, with a single marker signal as the determinant (Tobias et al. 2005). The observed negative ion marker, $m / z 421^{-}$, was tentatively attributed to a sulfolipid precursor earlier identified by independent methods as a component of the M. tuberculosis. Although there are just a few of these micro-organism studies, it is obvious that the focus in research on single particle LDI MS has shifted from technology exploration and development to the originally envisaged applications.

These few studies with biological material show that single particle LDI MS still holds some promise for bio-aerosol analysis. The sensitivity seems to be sufficient to give marker 


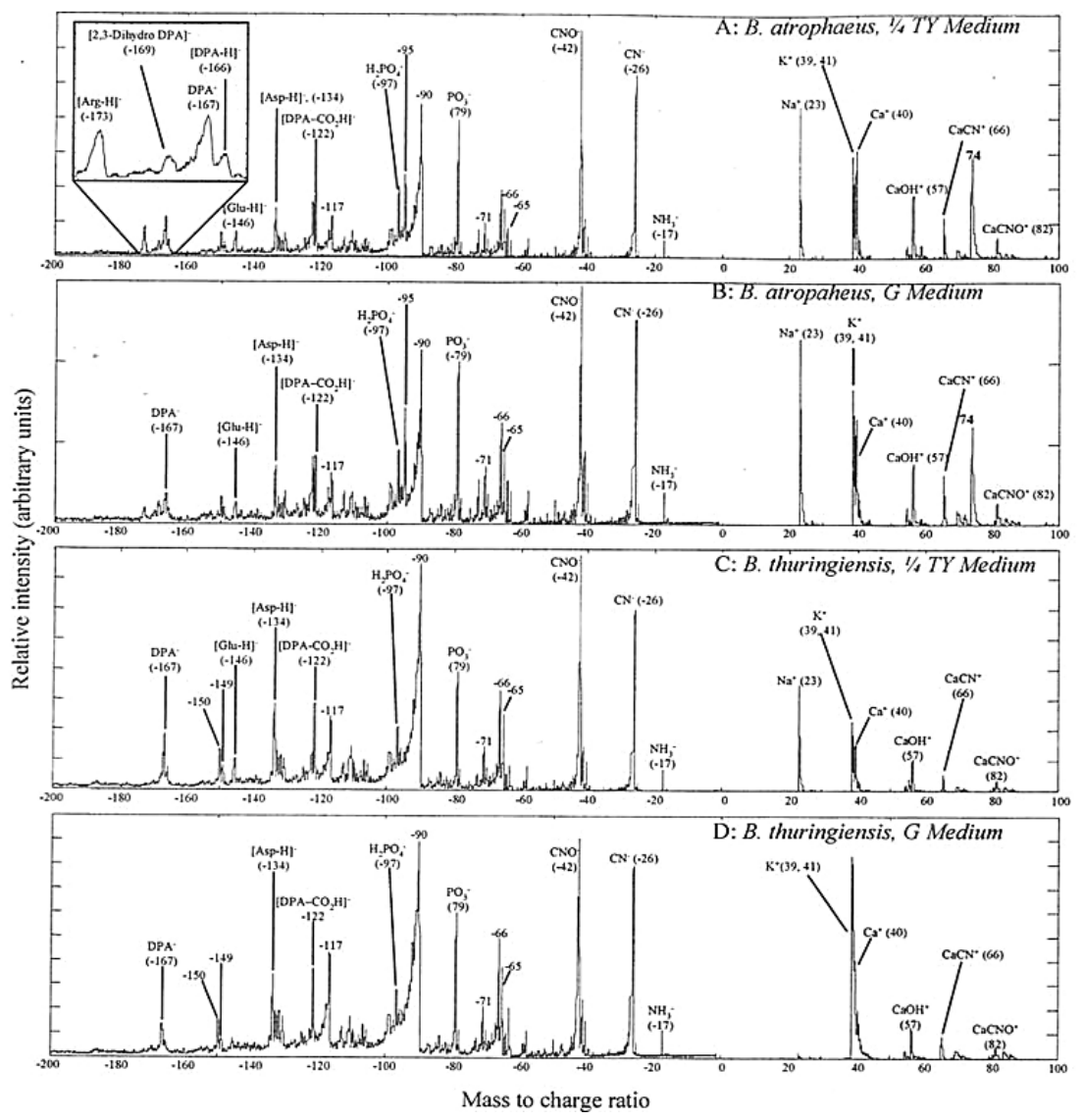

Figure 36.8. Combined axis positive and negative ion mass spectra obtained from averaging single particle LDI spectra of B. thuringiensis and B. atropheus after culturing on different growth media (Reprinted with permission from Fergenson et al. 2004. Copyright 2004 American Chemical Society).

signals from single particles. As the spectrum quality is concerned, there seems to be a strong analogy with the original pyrolysis mass spectra of bacteria, obtained in the 1970s and 1980s. Spectra typically display complicated patterns, with variable reproducibility and one or few biomarker signals. Many more microorganisms will have to be investigated to get to a more definite picture of single particle LDI capabilities.

\subsection{Single Particle MALDI MS Technology}

The step from single particle LDI MS to single particle MALDI MS seems logical by the historic analogy of the development of LDI and MALDI for bio-analysis. For single particle MS, this step is relatively easy when a matrix compound is mixed with the sample, prior to aerosolization. This was demonstrated with aerosols of bradykinin, gramicidin $\mathrm{S}$, and myoglobin and $\alpha$-cyano-4-hydroxycinnamic acid matrix (Murray et al. 1996), of leucine and of peptides (enkephalin and gramicidin S) mixed with several matrix compounds (Mansoori, Johnston, and Wexler, 1996) and with aerosols of gramicidin S with 3-nitrobenzyl alcohol as the matrix (Weiss 1997). At that time, the mass range and some other equipment limitations of typical single particle LDI mass spectrometers did not allow a full exploration of the premixed matrix 
approach. In addition, premixing of the matrix had little relevance in environmental aerosol research and in bio-aerosol detection. However, in the development of bio-analytical MS for laboratory applications there is a need for online coupling of MALDI MS with liquid flows from continuous separation methods (Foret and Preisler 2002; Gelpí 2002), for example with liquid chromatography (Murray et al. 1996; Preisler, Foret, and Karger 1998; Miliotis et al. 2000) or capillary electrophoresis (Zhang and Caprioli 1996). Therefore, the development of single particle MALDI MS follows two lines of sample treatment, either with matrix premixing prior to aerosolization or with online, in-flight coating of aerosol particles.

With the focus on bioaerosol mass spectrometry, interfacing of liquid based separations with single particle aerosol MALDI MS provides some insight into the performance of potential bio-aerosol mass spectrometer equipment. With various matrix compounds and several UV wavelengths employed, it is reported that the required matrix-to-analyte ratio lies between 10:1 and 1000:1 (Beeson, Murray, and Russell 1995; Mansoori, Johnston, and Wexler, 1996; He and Murray 1999). Although the quantity in a single particle of pure analyte lies between $100 \mathrm{amol}$ and $10 \mathrm{fmol}$, the analyte loss by interfacing through aerosolization implies that the overall analysis method is relatively insensitive. However, this analyte loss depends strongly on the design of the interface, and actual numbers for the analyte loss are not available. Because MALDI MS of deposited material does not ionize all of the deposited analyte, aerosol MALDI MS is still able to compete favorably. At present, chromatography interfacing to mass spectrometry is still in the research stage of development.

Analysis of environmental bio-aerosol particles by single particle MALDI MS requires inflight coating. Particle coating has found application in existing technology (see, e.g., Agarwal and Sem 1980). In principle, matrix coating by condensation can be accomplished by subsequent particle passage through a warm saturated vapor and a cold zone (Fig. 36.9). Upon cooling, the oversaturated vapor condenses on the aerosol particles, which are the only available condensation nuclei. These coated particles are then analyzed by a single particle TOF mass spectrometer (Stowers et al. 2000; Jackson, Mishra, and Murray 2004). In the coating process, the final particle size depends on the initial size, the temperature difference between hot and cold zone, the aerosol number concentration, and the sampling rate. These parameters were employed to tune the matrix-to-analyte ratio to produce MALDI mass spectra of acceptable quality. In a proof of principle, spectra were obtained from Gramicidine $\mathrm{S}$ and from Bacillus subtilis var niger (known as BG), and BG signals were tentatively assigned to peptidoglycan typical for BG cells (Stowers et al. 2000). This proof of principle showed that single particle MALDI TOF MS is possible.

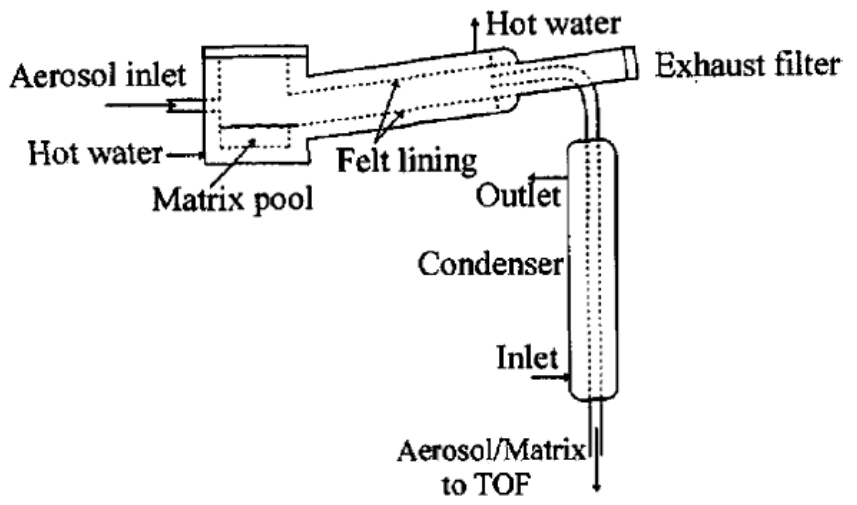

Figure 36.9. Schematic of an in-flight matrix coating apparatus for aerosol particles (from Van Wuijckhuijse et al. 2005b; reproduced with kind permission of Springer Science and Business Media). 
The initial equipment was augmented with new ion optics to extend the mass range, and with a triggering mechanism for selective ionization of biological particles (Stowers et al. 2002; Van Wuijckhuijse et al. 2005a and 2005b). The earlier observations for BG were reproduced and additional signals were found in the 6000-7500 Da mass range. The improvements allowed regeistration of mass spectra in the 1 to $30 \mathrm{kDa}$ range found relevant to whole cell bacteria typing in common MALDI (see above).

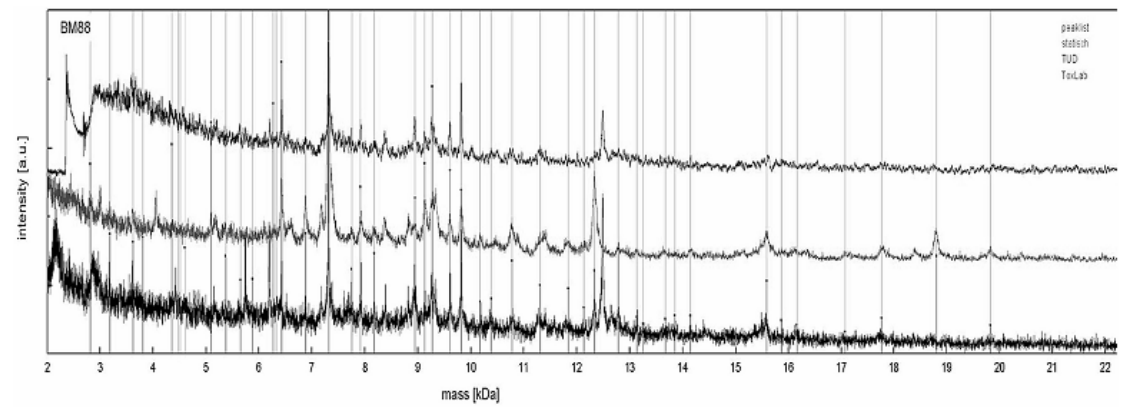

Figure 36.10. Spectra from "crushed crystallized" E. coli obtained on a common MALDI MS instrument (top trace; Biflex III MALDI mass spectrometer $337 \mathrm{~nm}$ ionization laser, average of 100 shots; Bruker Daltonics; Bremen, Germany) on two different direct MALDI ATOFMS instruments (middle: Delft University of Technology instrument with $308 \mathrm{~nm}$ ionization; bottom: instrument at TNO, with $337 \mathrm{~nm}$ ionization; both average of $\sim 1000$ single particle spectra); vertical lines represent the mass spectrum peak list.

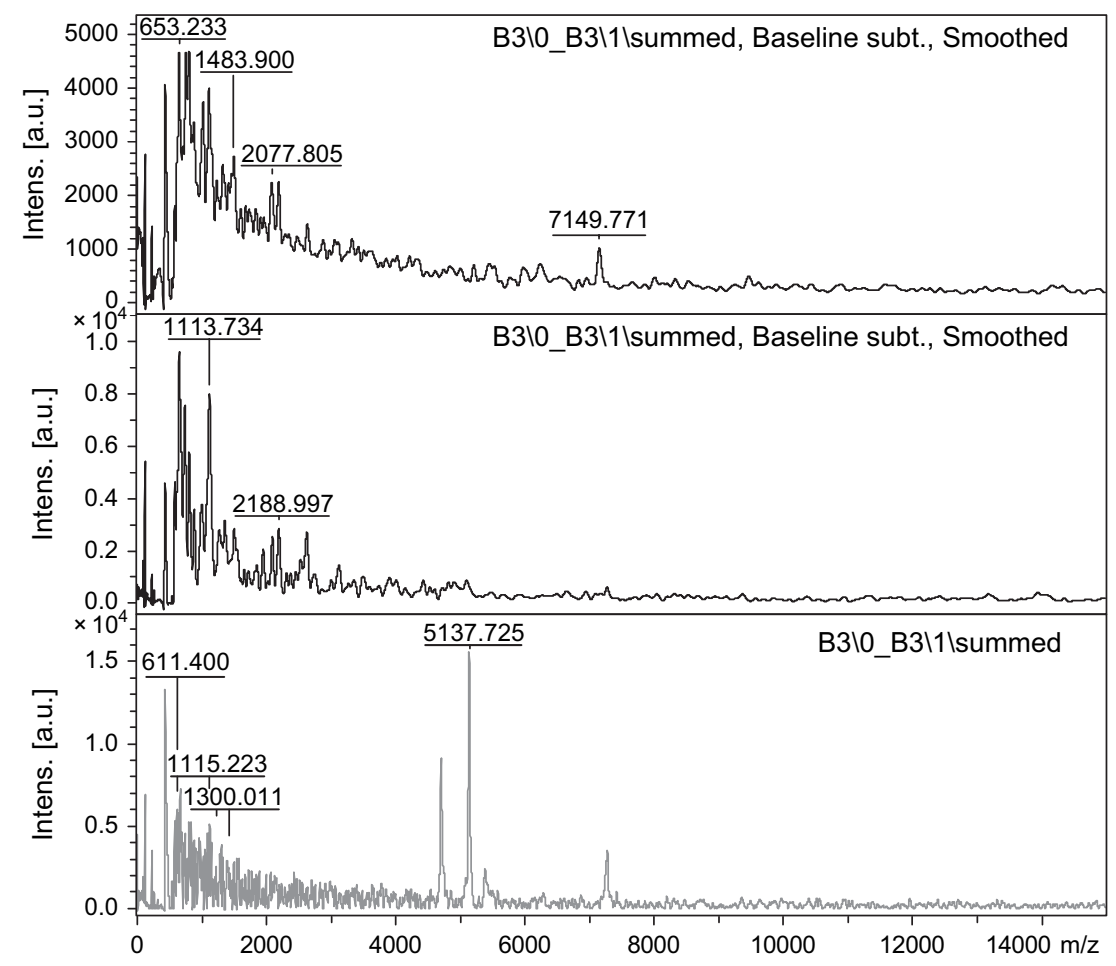

Figure 36.11. Direct Aerosol MALDI TOF mass spectra from B. globigii (top), B. thuringiensis (middle), and B. cereus (bottom) spores, obtained from the aerosolized spores and with spectrum averaging of $\sim 500$ particles. 
Over the last year, work has been going on to improve matrix coating, to become reproducible, and to build a prototype transportable system (Lok, 2007; Van Wuijckhuijse et al. in preparation). This will show whether single particle MALDI MS gives signatures that compare to those from whole cell MALDI MS in the laboratory. In a first step, Escherichia coli was prepared for a laboratory MALDI experiment by the common addition of matrix. Part of the crystallized material was collected and crushed to allow subsequent aerosolization. As it is shown in Fig. 36.10, analysis of this material with two different aerosol TOF mass spectrometers and with a common laboratory instrument yielded similar spectra. Although this single experiment requires repetition with a few more organisms, the spectrum resemblance demonstrates that spectrum matching of spectra from a single particle MALDI MS instrument with those from common whole-cell MALDI MS will support bacterial typing. The improved performance of the present system (Van Wuijckhuijse in preparation) is also demonstrated by single particle MALDI MS averaged spectra from several Bacillus species: B. thuringiensis, BG, and B. cereus (Fig. 36.11). These 500 particle average spectra, evaluated in their entirety and not yet by biomarker signals, clearly discriminate between the three closely related Bacillus species, and they also discriminate between spores and vegetative cells.

\section{Conclusions and Future Perspectives}

Bio-aerosol MS is still in the early stages of development, with 10 to 20 research groups world wide investigating the various technologies. In general, technology development tends toward increasing transportability, ruggedness, and ease of operation. That tendency is driven by the potential applications, which all involve in situ measurement for quick and reliable detection: medical, environmental, as well as civil and military safety applications. Where potential military and civil safety bio-aerosol MS is pretty much limited to the scope of threat perception, medical and environmental bio-aerosol MS may open up a completely new view of the world. We will become able to "see" microorganisms in environments where we have been blind until now. Of course, this sense of science fiction translates into some practical requirements for science and technology development. In this outlook we do not pretend to be exhaustive, but we pick up on a few issues for improvement of bio-aerosol MS in the next few years.

For bio-aerosol analysis, pyMS is currently best developed among the aerosol MS technologies. Given the fact that, so far, pyGC-ion mobility spectrometry (IMS) was developed for field bio-aerosol detection (Snyder et al. 2004), the technology and chemistry of FAME pyMS can be further developed for bio-aerosol detection (Krebs et al. 2006; Prasad et al. 2006). Changing from MS to IMS technology does resolve design issues with regard to size and transportability of the overall system. Although pyMS has the advantage that it does not include relatively vulnerable lasers, the use of laser ionization may greatly aid the selectivity in ionization of specific pyrolysis products. For example, photoionization was demonstrated for the analysis of polymers by pyMS (see, e.g., Zoller et al. 1999), for the field analysis of chemical weapons agents (Syage, Hanning-Lee, and Hanold 2000), and for the direct analysis of biological material (Evans, Hanold, and Syage 2000; Nies, Evans, and Syage 2003). Alternatively, surface ionization might give useful results when applied to bio-aerosols. Surface ionization is already employed in aerosol MS (e.g., Jimenez et al. 2003), but the published applications were limited to organic and inorganic aerosols. Simplification of the instrument by going from MS to IMS and application of other ionization modes, such as photoionization or surface ionization, may provide new signatures for the analysis of bio-aerosol components.

For all bio-aerosol MS technologies, downsizing is an important issue on the way to increased transportability. Downsizing applies to all of the component technologies integrated in a bio-aerosol mass spectrometer. Downsizing of the mass spectrometer has the additional 
benefit that smaller vacuum volumes require less pumping capacity and, hence, smaller pumps. The application of Ion Trap MS instead of TOF MS will sometimes be an option in downsizing, and we see Ion Trap MS (e.g., Harris, Reilly, and Whitten 2006) as a viable line of development in bio-aerosol MS. However, both types of mass spectrometer have proved amenable to downsizing, as has been reviewed by Badman and Cooks (2000). Downsizing often involves application of different or refined physical principles, with a concomitant redesign of the mass analyzer. The application of higher order ion focusing and a redesign of the instrument has for example produced small "end cap" reflectron TOF instruments with capabilities comparable to those of common laboratory TOF instruments (e.g., Cornish and Cotter 1997; Fancher, Woods, and Cotter 2000). A completely different way was pursued with the redesign of the reflectron from the common multistage to a single stage element (Uphoff, Muskat, and Grotemeyer 2004). Also, developments in the manufacturing process have led to smaller TOF instruments, even down to suitcase size (Cornish, Ecelberger, and Brinckerhoff 2000; Ecelberger et al. 2004). Downsizing of Ion Traps to a hand-portable size was recently accomplished (Song et al. 2006; Gao et al. 2006), although it should be noted that the mass range of such small Ion Traps is not yet compatible with high mass range applications. For either TOF or Ion Trap instruments, downsizing of the mass spectrometer will require tailoring to the specific application. Downsizing of laser systems will also drastically reduce the system size of LDI or MALDI bio-aerosol MS systems, with the additional benefit that smaller lasers require less cooling. The development of lasers is mainly driven by other applications, but more specific requirements for (aerosol) mass spectrometry have recently been pointed out in great detail (Holle et al. 2006; Murphy 2006). In particular, the development of solid-state lasers with UV capability will help in downsizing bio-aerosol MS systems. Downsizing of laser equipment and mass analyzers will determine the overall system downsizing, because aerosol sampling and capture equipment will not be amenable to much downsizing given the required performance.

For all bio-aerosol technologies, data handling is of the essence. Spectrum comparison with library spectra is a routine application, but actual identification of bacteria from spectra requires more research. For any of the bio-aerosol analysis methods applied to bacteria, robustness of the signature towards environmental factors and phenotype requires more research. The signatures obtained from pyMS and LDI approaches will not have sufficient distinctive capability for adequate identification, because the ionized material is essentially a far derivative of biological material. Nevertheless, in the analysis of bacterial bio-aerosols, pyMS and LDI signatures may be useful as indicators rather than identifiers. As for the MALDI MS approach to bio-aerosol analysis, the obtained signatures relate directly to bacterial biomolecules present. However, more research is required to establish the link between aerosol MALDI MS signature and bacterial biomolecules. On the basis of the current state of the art in laboratory MALDI MS of bacteria, direct aerosol MALDI MS has the potential to become a rapid identification method.

In conclusion, bio-aerosol MS still poses a challenge to science and technology, with interesting promises of environmental, medical and safety applications to be fulfilled in the next few years.

\section{References}

Abel K, DeSchmertzing H and Peterson JI (1963) Classification of Microorganisms by Analysis of Chemical Composition .1. Feasibility of Utilizing GC. J. Bacteriol. 85:1039-1044

Agarwal JK and Sem GJ (1980) Continuous Flow, Single-particle-counting Condensation Nucleus Counter. J. Aerosol Sci. 11:343-357

Al Dahouk S, Nöckler K, Scholz HC, Tomaso H, Bogumil R and Neubauer H (2006) Immunoproteomic Characterization of Brucella abortus 1119-3 Preparations used for the Serodiagnosis of Brucella Infections. J. Immunol. Meth. 309:34-47 
Altelaar AFM, Van Minnen J, Jimenez CR, Heeren RMA and Piersma SR (2005) Direct Molecular Imaging of Lymnaea stagnalis Nervous Tissue at Subcellular Spatial Resolution by Mass Spectrometry. Anal. Chem. 77:735-741

Anderson CW and Carlson MA (1999) A Time-of-Flight Mini-Mass Spectrometer: Aerosol Collection, Capture, and Load-Lock System. Johns Hopkins APL Tech. Dig. 20:352-362

Anderson CW, Scholl PF, Chappell RG, Bryden WA, Ko HW and Ecelberger SA (2003) Sample Collection Preparation for Time-of-flight Miniature Mass Spectrometer. US Patent 5,806,465

Antoine MD, Carlson MA, Drummond WR, Doss III OW, Hayek CS, Saksena A and Lin JS (2004) Mass Spectral Analysis of Biological Agents Using the BioTOF Mass Spectrometer. Johns Hopkins APL Tech. Dig. 25:20-26

Arnold RJ and Reilly JP (1998) Fingerprint matching of e. coli strains with matrix-assisted laser desorption ionization time-of-flight mass spectrometry of whole cells using a modified correlation approach. Rapid. Commun. Mass Spectrom. 12:630-636

Arnold RJ, Karty JA, Ellington AD and Reilly JP (1999) Monitoring the Growth of a Bacteria Culture by MALDI MS of Whole Cells. Anal. Chem. 71:1990-1996

Badman ER and Cooks RG (2000) Miniature Mass Analyzers. J. Mass Spectrom. 35:659-671

Balasanmugam K, Dang TA, Day RJ, and Hercules DM (1981) Some Cation and Anion Attachment Reactions in Laser Desorption Mass Spectrometry. Anal. Chem. 53:2296-2298

Balasanmugam K, Viswanadham SK and Hercules D (1986) Characterization of Polycyclic Aromatic Hydrocarbons by Laser Mass Spectrometry. Anal. Chem. 58:1102-1108

Barshick SA, Wolf DA and Vass AA (1999) Differentiation of Microorganisms Based on Pyrolysis - Ion Trap Mass Spectrometry Using Chemical Ionization. Anal. Chem. 71:633-641

Basile F, Beverly MB, Abbas-Hawks C, Mowry CD, Voorhees KJ and Hadfield TL (1998) Direct Mass Spectrometric Analysis of In Situ Thermally Hydrolyzed and Methylated Lipids from Whole Bacterial Cells. Anal. Chem. 70:1555-1562

Beeson MD, Murray KK and Russell DH (1995) Aerosol Matrix-Assisted Laser Desorption Ionization: Effects of Analyte Concentration and Matrix-to-Analyte Ratio. Anal. Chem. 67:1981-1986

Beverly MB, Basile F, Voorhees KJ and Hadfield TL (1996) A Rapid Approach for the Detection of Dipicolinic Acid in Bacterial Spores Using Pyrolysis/Mass Spectrometry. Rapid. Commun. Mass Spectrom. 10:455-458

Böhm R, Kapr T, Schmitt HU, Albrecht J and Wieser P (1985) Application of the Laser Microprobe Mass Analyser (LAMMA) to the Differentiation of Single Bacterial Cells. J. Anal. Appl. Pyrol. 8:449-461

Brockman AH and Orlando R (1995). Probe-immobilized Affinity Chromatography/Mass Spectrometry. Anal. Chem. 67:4581-4585

Bruynseels F and Van Grieken RE (1984) Laser Microprobe Mass Spectrometric Identification of Sulfur Species in Single Micrometer-size Particles. Anal. Chem. 56:871-873

Bruynseels F, Storms H, Van Grieken R and Van der Auwera L (1988) Characterization of North Sea Aerosols by Individual Particle Analysis. Atmosph. Environm. 22:2593-2602

Bryden WA, Benson RC, Ecelberger SA, Phillips TE, Cotter RJ and Fenselau C (1995) The Tiny-TOF MassSpectrometer for Chemical and Biological Sensing. Johns Hopkins APL Tech. Dig. 16:296-310

Bundy J and Fenselau C (1999) Lectin-based Affinity Capture for MALDI-MS Analysis of Bacteria., Anal. Chem. 71:1460-1463

Caputo E, Moharram R and Martin BM (2003) Methods for On-chip Protein Analysis. Anal. Biochem. 321:116-124

Carson PG, Neubauer KR, Johnston MV and Wexler AS (1995) On-line Chemical Analysis of Single Aerosol Particles by Rapid Single-particle Mass Spectrometry. J. Aeros. Sci. 26:535-545

Claydon MA, Davey SN, Edwards-Jones V and Gordon DB (1996) The Rapid Identification of Intact Microorganisms Using Mass Spectrometry. Nat. Biotechnol. 14:1584-1586

Cornish TJ and Cotter RJ (1992) A Compact TOF-MS for the Structural Analysis of Biological Molecules Using Laser Desorption. Rapid Comm. Mass Spectrom. 6:242-248

Cornish TJ and Cotter RJ (1997) High-order Kinetic Energy Focusing in an End Cap Reflectron Time-of-flight Mass Spectrometer. Anal. Chem. 69:4615-4618

Cornish TJ, Ecelberger S and Brinckerhoff W (2000) Miniature Time-of-flight Mass Spectrometer Using a Flexible Circuitboard Reflector. Rapid Commun. Mass Spectrom. 14:2408-2411

Cotter RJ (1980) Laser Desorption Chemical Ionization Mass Spectrometry. Anal. Chem. 52:1767-1770

Cotter RJ (1981) Cationized Species in Laser Desorption Mass Spectrometry. Anal. Chem. 53:719-720

Dai Y, Whittal RM and Li L (1996) Confocal Fluorescence Microscopic Imaging for Investigating the Analyte Distribution in MALDI Matrices. Anal. Chem. 68:2494-2500

Dale JM, Yang M, Whitten WB and Ramsey JM (1994) Chemical Characterization of Single Particles by Laser Ablation/Desorption in a Quadrupole Ion-Trap Mass-Spectrometer. Anal. Chem. 66:3431-3435

DeLuca S, Sarver EW, Harrington PD and Voorhees KJ (1990) Direct Analysis of Bacterial Fatty Acids by Curie-point Pyrolysis Tandem Mass Spectrometry. Anal. Chem. 62:1465-1472

DeLuca SJ, Sarver EW and Voorhees KJ (1992) Direct Analysis of Bacterial Glycerides by Curie-point Pyrolysis Mass Spectrometry. J. Anal. Appl. Pyrolysis 23:1-14 
Demirev PA, Ho YP, Ryzhov V and Fenselau C (1999) Micro-organism Identification by Mass Spectrometry and Protein Database Searches., Anal. Chem. 71:2732-2738

Demirev PA, Lin JS, Pineda FJ and Fenselau C (2001) Bioinformatics and Mass Spectrometry for Micro-organism Identification: Proteome-wide Post-translational Modifications and Database Search Algorithms for Characterization of Intact H. pylori. Anal. Chem. 73:4566-4573

Dickinson DN, La Duc MT, Haskins WE, Gornushkin I, Winefordner JD, Powell DH and Venkateswaran K (2004) Species Differentiation of a Diverse Suite of Bacillus Spores by Mass Spectrometry-Based Protein Profiling. Appl. Envir. Microbiol. 70:475-482

Dierck I, Michaud D, Wouters L and Van Grieken R (1992) Laser Microprobe Mass Analysis of Individual North Sea Aerosol Particles. Environ. Sci. Technol. 26:802-808

Ecelberger SA, Cornish TJ, Collins BF, Lewis DL and Bryden WA (2004) Suitcase TOF: A Man-Portable Time-ofFlight Mass Spectrometer. Johns Hopkins APL Tech. Dig. 25:14-19

Engwegen JYMN, Gast M-CW, Schellens JHM and Beijnen JH (2006) Clinical Proteomics: Searching for Better Tumour Markers with SELDI-TOF Mass Spectrometry. Tr. Pharmacol. Sci. 27:251-259

Evans MD, Hanold KA and Syage JA (2000) Rapid Response Chem/Bio Detection System Based on Photoionization Mass Spectrometry. Proc. 1st Joint Conf. for CB Defense, Oct 23-27, Williamsburg, Virginia

Evason DJ, Claydon MA and Gordon DB (2001) Exploring the Limits of Bacterial Identification by Intact Cell - Mass Spectrometry. J. Am. Soc. Mass Spectrom. 12:49-54

Fancher CA, Woods AS and Cotter RJ (2000) Improving the Sensitivity of the End-cap Reflectron Time-of-flight Mass Spectrometer. J. Mass Spectrom. 35:157-162

Fenselau C and Demirev PA (2001) Characterization of Intact Microorganisms by MALDI Mass Spectrometry. Mass Spectrom. Rev. 20:157-171

Fergenson DP, Pitesky ME, Tobias HJ, Steele PT, Czerwieniec GA, Russell SC, Lebrilla C, Horn J, Coffee K, Srivastava A, Pillai SP, Shih M-TP, Hall HL, Ramponi AJ, Chang JT, Langlois RG, Estacio PL, Hadley RT, Frank M and Gard E (2004) Reagentless Detection and Classification of Individual Bioaerosol Particles in Seconds. Anal. Chem. 76:373-378

Foret F and Preisler J (2002) Liquid Phase Interfacing and Miniaturization in Matrix-Assisted Laser Desorption / Ionization Mass Spectrometry. Proteomics 2:360-372

Fox A (2006) Mass Spectrometry for Species or Strain Identification After Culture or Without Culture: Past, Present, and Future. J. Clin. Microbiol. 44:2677-2680

Freeman R, Sisson PR and Ward AC (1995) Resolution of Batch Variations in Pyrolysis Mass Spectrometry of Bacteria by the Use of Artificial Neural Network Analysis. Antonie Van Leeuwenhoek 68:253-260

Gao L, Song Q, Patterson GE, Cooks RG and Ouyang Z (2006) Handheld Rectilinear Ion Trap Mass Spectrometer. Anal. Chem. 78:5994-6002

Gard E, Mayer JE, Morrical BD, Dienes T, Fergenson DP and Prather KA (1997) Real-time Analysis of Individual Atmospheric Aerosol Particles: Design and Performance of a Portable ATOFMS. Anal. Chem. 69:4083-4091

Gardner B. D., Donaldson, W., Chun, R., Lee, W. T., Tissandier, M. 2005. An Ion Trap Mass Spectrometer System for Continuous Monitoring of Biological and Chemical Backgrounds. Proc. 5th Harsh-Environment Mass Spectrometry Workshop, September 20-23, Sarasota, Florida

Gelpí E (2002) Interfaces for Coupled Liquid-Phase Separation / Mass Spectrometry Techniques. An Update on Recent Developments. J. Mass Spectrom. 37:241-253

Glass K and Becker NG (2006) Evaluation of Measures to Reduce International Spread of SARS. Epidemiol. Infect. 134:1092-1101

Goodacre R, Shann B, Gilbert RJ, Timmins EM, McGovern AC, Alsberg BK, Kell DB and Logan NA (2000) Detection of the Dipicolinic Acid Biomarker in Bacillus Spores Using Curie-point Pyrolysis Mass Spectrometry and Fourier Transform Infrared Spectroscopy. Anal. Chem. 72, 119-127

Griest WH, Wise MB, Hart KJ, Lammert SA, Thompson CV and Vass AA (2001) Biological Agent Detection and Identification by the Block II Chemical Biological Mass Spectrometer. Field Analyt. Chem. Technol. 5:177-184

Hamburg MA (2002) Bioterrorism: Responding to an Emerging Threat. Trends Biotechnol. 20:296-298

Hara K, Kikuchi T, Furuya K, Hayashi M and Fujii Y (1996) Characterization of Antarctic Aerosol Particles Using Laser Microprobe Mass Spectrometry. Environ. Sci. Technol. 30:385-391

Harris WA, Reilly PTA and Whitten WB (2006) Aerosol MALDI of Peptides and Proteins in an Ion Trap Mass Spectrometer: Trapping, Resolution and Signal-to-noise. Int. J. Mass Spectrom. 258:113-119

Hart KJ, Harmon SH, Wolf DA, Vass AA and Wise MB (1999) Detection of Chemical/Biological Agents and Simulants Using Quadrupole Ion Trap Mass Spectrometry. Proceedings of the 47th ASMS Conf. Mass Spectrom. All. Topics, June 13-17, Dallas, TX

Hart KJ, Wise MB, Griest WH and Lammert SA (2000) Design, Development and Performance of a Fieldable Chemical and Biological Agent Detector. Field Anal. Chem. Technol. 4:93-110

Hathout Y, Demirev PA, Ho Y-P, Bundy JL, Ryzhov V, Sapp L, Stutler J, Jackman J and Fenselau C (1999) Identification of Bacillus Spores by Matrix-assisted Laser Desorption Ionization - Mass Spectrometry. Appl. Environ. Microbiol. 65:4313-4319 
Hathout Y, Setlow B, Cabrera-Martinez R-M, Fenselau C and Setlow P (2003) Small, Acid-Soluble Proteins as Biomarkers in Mass Spectrometry Analysis of Bacillus Spores. Appl. Envir. Microbiol. 69:1100-1107

He L and Murray KK (1999) 337 nm Matrix-Assisted Laser Desorption / Ionization of Single Aerosol Particles. J. Mass Spectrom. 34:909-914

Heller DN, Fenselau C, Cotter RJ, Demirev P, Olthoff JK, Honovich J, Uy M, Tanaka T and Kishimoto Y (1987) Mass Spectral Analysis of Complex Lipids Desorbed Directly from Lyophilized Membranes and Cells. Biochem. Biophys. Res. Commun. 142:194-199

Hillenkamp F, Unsöld E, Kaufmann R and Nitsche R (1975) A High Sensitivity Laser Microprobe Mass Analyzer. Appl. Phys. 8:341-348.

Hinz KP, Kaufmann R and Spengler B (1994) Laser-Induced Mass Analysis of Single Particles in the Airborne State. Anal. Chem. 66:2071-2076

Holland RD, Wilkes JG, Rafii F, Sutherland JB, Persons CC, Voorhees KJ and Lay JO (1996) Rapid Identification of Intact Whole Bacteria Based on Spectral Patterns Using Matrix Assisted Laser Desorption / Ionization with Time-of-flight Mass Spectrometry. Rapid. Commun. Mass. Spectrom. 10:1227-1232

Holland RD, Rafii F, Heinze TM, Sutherland JB, Voorhees KJ and Lay Jr. JO (2000) Matrix-Assisted Laser Desorption/Ionization Time-of-Flight Mass Spectrometric Detection of Bacterial Biomarker Proteins Isolated from Contaminated Water, Lettuce and Cotton Cloth. Rapid. Commun. Mass. Spectrom. 14:911-917

Holle A, Haase A, Kayser M and Höhndorf J (2006) Optimizing UV Laser Focus Profiles for Improved MALDI Performance. J. Mass Spectrom. 41:705-716

Hutchens TW and Yip TT (1993) New Desorption Strategies for the Mass Spectrometric Analysis of Macromolecules. Rapid Commun. Mass Spectrom. 7:576-580

Jackson SN, Mishra S and Murray KK (2004) On-line Laser Desorption/Ionization Mass Spectrometry of Matrix-coated Aerosols. Rapid Comm. Mass Spectrom. 18:2041-2045

Jarman KH, Daly DS, Petersen CE, Saenz AJ, Valentine NB and Wahl KL (1999) Extracting and Visualizing Matrixassisted Laser Desorption/Ionization Time-of-flight Mass Spectral Fingerprints. Rapid. Commun. Mass. Spectrom. 13:1586-1594

Jarman KH, Cebula ST, Saenz AJ, Petersen CE, Valentine NB, Kingsley MT and Wahl KL (2000) An Algorithm for Automated Bacterial Identification Using Matrix-assisted Laser Desorption/Ionization Mass Spectrometry. Anal. Chem. 72:1217-1223

Jimenez JL, Jayne JT, Shi Q, Kolb CE, Worsnop DR, Yourshaw I, Seinfeld JH, Flagan RC, Zhang X, Smith KA, Morris JW and Davidovits P (2003) Ambient Aerosol Sampling Using the Aerodyne Aerosol Mass Spectrometer. J. Geophys. Res. 108:8425

Jones JJ, Wilkins CL, Cai Y, Beitle RR, Liyanage, R., and Lay Jr., J. O. 2005 Real-time Monitoring of Recombinant Bacterial Proteins by Mass Spectrometry. Biotechnol. Prog. 21:1754-1758.

Karas M and Hillenkamp F (1988) Laser Desorption Ionization of Proteins with Molecular Masses Exceeding 10,000 Daltons. Anal Chem. 60:2299-2301

Karas M and Krüger R (2003) Ion Formation in MALDI: The Cluster Ionization Mechanism., Chem. Rev. 103:427-439

Kaufmann R, Hillenkamp F and Wechsung R (1979) The Laser Microprobe Mass Analyzer (LAMMA): A New Instrument for Biomedical Microprobe Analysis. Med. Prog. Technol. 6:109-121

Keys CJ, Dare DJ, Sutton H, Wells G, Lunt M, McKenna T, McDowall M and Shah HN (2004) Compilation of a MALDI-TOF Mass Spectral Database for the Rapid Screening and Characterisation of Bacteria Implicated in Human Infectious Diseases. Infect. Genet. Evol. 4:221-242

Kievit O, Marijnissen JCM, Verheijen PJT and Scarlett B (1992) On-line Measurement of Particle Size and Composition. J. Aerosol Sci. 23, Suppl. 1:301-304

Kievit O, Weiss M, Verheijen PJT, Marijnissen JCM and Scarlett B (1996) The On-line Chemical Analysis of Single Particles Using Aerosol Beams and Time of Flight Mass Spectrometry. Chem. Eng. Commun. 151:79-100

Knochenmuss R and Zenobi R (2003) MALDI Ionization: The Role of In-plume Processes., Chem. Rev. 103:441-452

Krebs MD, Mansfield B, Yip P, Cohen SJ, Sonenshein AL, Hitt BA and Davis CE (2006) Novel Technology for Rapid Species-specific Detection of Bacillus Spores. Biomol. Eng. 23:119-127

Krishnamurthy $\mathrm{T}$ and Ross PL (1996) Rapid Identification of Bacteria by Direct Matrix-assisted Laser Desorption/Ionization Mass Spectrometric Analysis of Whole Cells. Rapid Commun. Mass Spectrom. 10:1992-1996

Kussman M, Nordhof E, Rahbek-Nielsen H, Haebel S, Rossel-Larsen M, Jakobsen L, Gobom J, Mirgorodskaya E, KrollKristensen A, Palm L and Roepstorff P (1997) Matrix-assisted Laser Desorption / Ionization Mass Spectrometry Sample Preparation Techniques Designed for Various Peptide and Protein Analytes. J. Mass Spectrom. 32:593-601

Kyne L, Merry C, O’Connell B, Harrington P, Keane C and O’Neill D (1998) Simultaneous Outbreaks of Two Strains of Toxigenic Clostridium difficile in a General Hospital. J. Hosp. Infect. 38:101-112

Lammert SA, Griest WH, Wise MB, Hart KJ, Vass AA, Wolf DA, Burnett MN, Merriweather R and Smith RR (2002) A Mass Spectrometer-based System for Integrated Chemical and Biological Agent Detection - The Block II CBMS. Proceedings of the 50th ASMS Conf. Mass Spectrom. All. Topics, June 2-6, Orlando, Florida 
Lay Jr. JO (2000) MALDI-TOF Mass Spectrometry and Bacterial Taxonomy. Tr. Anal. Chem. 19:507-516

Lay Jr. JO (2001) MALDI-TOF Mass Spectrometry of Bacteria. Mass Spectrom. Rev. 20: 172-194

Liang XL, Lubman DM, Rossi DT, Nordblom GD and Barksdale CM (1998) On-probe Immunoaffinity Extraction by Matrix-assisted Laser Desorption/Ionization Mass Spectrometry. Anal. Chem. 70:498-503

Lok JJ (2007) Dutch Detector Promises Swift BW Analysis. Jane's Int. Def. Rev. 40:4

Luo S, Mohr J, Sickenberger D and Hryncewich A (1999) Study of Purified Bacteria and Viruses by Pyrolysis Mass Spectrometry. Field Analyt. Chem. Technol. 3:357-374

Luxembourg SL, McDonnell LA, Duursma M, Guo X and Heeren RMA (2003) Effect of Local Matrix Crystal Variations in Matrix-Assisted Ionization Techniques for Mass Spectrometry. Anal. Chem. 75:2333-2341

Macha SF and Limbach PA (2002) Matrix-assisted Laser Desorption/Ionization (MALDI) Mass Spectrometry of Polymers. Curr. Opin. Sol. State Mat. Sci. 6:213-220

Maier T, Große-Herrenthey A, Krueger M, Kelly J and Kostrzewa M (2006) Automated Microorganism Identification Using a Database Software System and a High Quality MALDI-TOF Spectra Library. Proceedings of the 17th Int. Mass Spectrom. Conf., 27 Aug.-1 Sept., Prague, Czech Republic

Mandrell RE, Harden LA, Bates A, Miller WG, Haddon WF and Fagerquist CK (2005) Speciation of Campylobacter coli, C. jejuni, C. helveticus, C. lari, C. sputorum, and C. upsaliensis by Matrix-assisted Laser Desorption Ionization - Time of Flight Mass Spectrometry. Appl. Environ. Microbiol. 71:6292-6307

Mansoori BA, Johnston MV and Wexler AS (1996) Matrix-Assisted Laser Desorption/Ionization of Size- and Composition Selected Aerosol Particles. Anal. Chem. 68:3595-3601

Marijnissen J, Scarlett B and Verheijen P (1988) Proposed On-line Aerosol Analysis Combining Size Determination, Laser-induced Fragmentation and Time-of-flight Mass Spectroscopy. J. Aerosol Sci. 19:1307-1310

Marvin LF, Roberts MA and Fay LB (2003) Matrix-assisted Laser Desorption/Ionization Time-of-flight Mass Spectrometry in Clinical Chemistry. Clin. Chim. Acta 337:11-21

McCracken D, Flanagan P, Hill D and Hosein I (2000) Cluster of Cases of Mycobacterium chelonae Bacteraemia. Eur. J. Clin. Microbiol. Infect. Dis. 19:43-46

McKeown PJ, Johnston MV and Murphy DM (1991) Online Single-particle Analysis by Laser Desorption MassSpectrometry. Anal. Chem. 63:2069-2073

Meuzelaar HLC and Kistemaker PG (1973) A Technique for Fast and Reproducible Fingerprinting of Bacteria by Pyrolysis Mass Spectrometry. Anal. Chem. 45:587-590

Miliotis T, Kjellstrom S, Nilsson J, Laurell T, Edholm LE and Marko-Varga G (2000) Capillary Liquid Chromatography Interfaced to Matrix-Assisted Laser Desorption-Ionization Time-of-Flight Mass Spectrometry Using an On-Line Coupled Piezoelectric Flow-through Microdispenser. J. Mass Spectrom. 35:369-377

Moss CW (1990) Use of Cellular Fatty Acids for Identification of Microorganisms. In: Fox A, Morgan LS, Larsson L and Odham G (eds) Analytical Microbiology Methods: Chromatography and Mass Spectrometry. Plenum Press, New York, pp 59-69

Murphy DM (2006) The Design of Single Particle Laser Mass Spectrometers., Mass Spectrom. Rev. 26:150-165

Murray KK, Lewis TM, Beeson MD and Russell DH (1996) Aerosol Matrix-Assisted Laser-Desorption Ionization for Liquid-Chromatography Time-of-Flight Mass-Spectrometry. Anal. Chem. 66:1601-1609

Nielen MWF (1999) MALDI Time-of-flight Mass Spectrometry of Synthetic Polymers. Mass Spectrom. Rev. 18:309-344

Nies BJ, Evans MD and Syage JA (2003) Rapid Biological Weapons Monitoring by Pyrolysis/GC, Photoionization MS., PITTCON, March 9-14, Orlando, Florida

Nilsson CL (1999) Fingerprinting of Helicobacter pylori Strains by Matrix-assisted Laser Desorption/Ionization Mass Spectrometric Analysis. Rapid Commun. Mass Spectrom. 13:1067-1071

Noble CA and Prather KA (2000) Real-time Single Particle Mass Spectrometry: A Historical Review of a Quarter Century of the Chemical Analysis of Aerosols. Mass Spectrom. Rev. 19:248-274

Oyama VI (1963) Mars Biological Analysis by Gas Chromatography. Lunar Planetary Expl. Coll. Proc. 3:29-36

Perdue ML and Swayne DE (2005) Public Health Risk from Avian Influenza Viruses. Avian Dis. 49:317-327

Pineda FJ, Lin JS, Fenselau C and Demirev PA (2000) Testing the Significance of Micro-organism Identification by Mass Spectrometry and Proteome Database Search. Anal. Chem. 72:3739-3744

Pineda FJ, Antoine MD, Demirev PA, Feldman AB, Jackman J, Longenecker M and Lin JS (2003) Micro-organism Identification by Matrix-Assisted Laser/Desorption Ionization Mass Spectrometry and Model-Derived Ribosomal Protein Biomarkers. Anal. Chem. 75:3817-3822

Poerschmann J, Parsi Z, Gorecki T and Augustin J (2005) Characterization of Non-discriminating Tetramethylammonium Hydroxide - Induced Thermochemolysis - Capillary Gas Chromatography - Mass Spectrometry as a Method for Profiling Fatty Acids in Bacterial Biomasses. J. Chromatogr. A. 1071:99-109

Posthumus MA, Kistemaker PG, Meuzelaar HLC and Ten Noever de Brauw MC (1978) Laser Desorption-Mass Spectrometry of Polar Nonvolatile Bio-organic Molecules. Anal. Chem. 50:985-991

Prasad S, Schmidt H, Lampen P, Wang M, Güth R, Rao JV, Smith GB and Eiceman GA (2006) Analysis of Bacterial Strains with Pyrolysis - Gas Chromatography / Differential Mobility Spectrometry. Analyst 131:1216-1225 
Prather KA, Nordmeyer T and Salt K (1994) Real-time Characterization of Individual Aerosol-Particles Using Timeof-Flight Mass-Spectrometry. Anal. Chem. 66:1403-1407

Preisler J, Foret F and Karger BL (1998) On-Line MALDI-TOF MS Using a Continuous Vacuum Deposition Interface. Anal. Chem. 70:5278-5287

Reiner E (1965) Identification of Bacterial Strains by Pyrolysis Gas-liquid Chromatography. Nature (London) 206:1272-1274

Saenz AJ, Petersen CE, Valentine NB, Gantt SL, Jarman KH, Kingsley M and Wahl KL (2001) Reproducibility of Matrix Assisted Laser Desorption/Ionization Time-of-flight Mass Spectrometry for Replicate Bacterial Culture Analysis. Rapid Commun. Mass Spectrom. 13:1580-1585

Schmid O, Ball G, Lancashire L, Culak R and Shah H (2005) New Approaches to Identification of Bacterial Pathogens by Surface Enhanced Laser Desorption/Ionization Time of Flight Mass Spectrometry in Concert with Artificial Neural Networks, with Special Reference to Neisseria gonorrhoeae. J. Med. Microbiol. 54:1205-1211

Schulten HR, Beckey HD, Meuzelaar HLC and Boerboom AJH (1973) High Resolution Field Ionization of Bacterial Pyrolysis Products Anal. Chem. 45:191-195

Schwartz SA, Reyzer ML and Caprioli RM (2003) Direct Tissue Analysis Using Matrix-assisted Laser Desorption/Ionization Mass Spectrometry: Practical Aspects of Sample Preparation. J. Mass Spectrom. 38:699-708

Seydel U, Lindner B, Seydel JK and Brandenburt K (1982) Detection of Externally Induced Impairments in Single Bacterial Cells by Laser Microbe Mass Analysis. Int. J. Lepr. Other Mycobact. Dis. 50:90-95

Seydel U and Lindner B (1988) Monitoring of Bacterial Drug Response by Mass Spectrometry of Single Cells. Biomed. Environ. Mass Spectrom. 16:457-459

Shute LA, Gutteridge CS, Norris JR and Berkeley RC (1984) Curie-point Pyrolysis Mass Spectrometry Applied to Characterization and Identification of Selected Bacillus Species. J. Gen. Microbiol. 130:343-355

Simmonds PG, Shulman GP and Stembridge CH (1969) Organic Analysis by Pyrolysis - Gas Chromatography Mass Spectrometry: A Candidate Experiment for the Biological Exploration of Mars J. Chromatogr. Sci. 7:36-41

Simmonds PG (1970) Whole Micro-organisms Studied by Pyrolysis Gas Chromatography - Mass Spectrometry: Significance for Extraterrestial Life Detection Experiments Appl. Microbiol. 20:567-572

Sinha MP (1984) Laser-Induced Volatilization and Ionization of Microparticles. Rev. Sci. Instrum. 55:886-891

Sinha MP, Platz RM, Friedlander SK and Vilker VL (1985) Characterization of Bacteria by Particle Beam Mass Spectrometry. Appl. Environ. Microbiol. 49:1366-1373

Snyder AP, Dworzanski JP, Tripathi A, Maswadeh WM and Wick CH (2004) Correlation of Mass Spectrometry Identified Bacterial Biomarkers from a Fielded Pyrolysis - Gas Chromatography - Ion Mobility Spectrometry Biodetector with the Microbiological Gram Stain Classification Scheme. Anal. Chem. 76:6492-6499

Song Y, Wu G, Song Q, Cooks RG, Ouyang Z and Plass WR (2006) Novel Linear Ion Trap Mass Analyzer Composed of Four Planar Electrodes. J. Am. Soc. Mass Spectrom. 17:631-639

Spiegelman D, Whissell G and Greer CW (2005) A Survey of the Methods for the Characterization of Microbial Consortia and Communities. Can. J. Microbiol. 51:355-386

Srivastava A, Pitesky ME, Steele PT, Tobias HJ, Fergenson DP, Horn JM, Russell SC, Czerwieniec GA, Lebrilla CB, Gard EE and Frank M (2005) Comprehensive Assignment of Mass Spectral Signatures from Individual Bacillus atrophaeus Spores in Matrix-Free Laser Desorption/Ionization Bioaerosol Mass Spectrometry. Anal. Chem. 77:3315-3323

Steele PT, Tobias HJ, Fergenson DP, Pitesky ME, Horn JM, Czerwieniec GA, Russell SC, Lebrilla CB, Gard EE and Frank M (2003) Laser Power Dependence of Mass Spectral Signatures from Individual Bacterial Spores in Bioaerosol Mass Spectrometry. Anal. Chem. 75:5480-5487

Steele PT, Srivastava A, Pitesky ME, Fergenson DP, Tobias HJ, Gard EE and Frank M (2005) Desorption/Ionization Fluence Thresholds and Improved Mass Spectral Consistency Measured Using a Flattop Laser Profile in the Bioaerosol Mass Spectrometry of Single Bacillus Endospores. Anal. Chem. 77:7448-7454

Stern NJ, Kotula AW and Pierson D (1979) Differentiation of Selected Enterobacteriaceae by Pyrolysis - Gas-liquid Chromatography. Appl. Environm. Microbiol. 38:1098-1102

Stoakes L, Kelly T, Schieven B, Harley D, Ramos M, Lannigan R, Groves D and Hussain Z (1991) Gas-Liquid Chromatography Analysis of Cellular Fatty Acids for Identification of Gram-Negative Anaerobic Bacilli. J. Clin. Microbiol. 29:2636-2638

Stoeckli M, Farmer TB and Caprioli RM (1999) Automated Mass Spectrometry Imaging with a Matrix-Assisted Laser Desorption Ionization Time-of-Flight Instrument. J. Am. Soc. Mass Spectrom. 10:67-71

Stoll R and Röllgen FW (1979) Laser Desorption Mass Spectrometry of Thermally Labile Compounds Using a Continuous Wave CO2 Laser. Org. Mass Spectrom. 14:642-645

Stowers MA, Van Wuijckhuijse AL, Marijnissen JCM, Scarlett B, Van Baar BLM and Kientz CE (2000) Application of Matrix-Assisted Laser Desorption/Ionization to On-line Aerosol Time-of-flight Mass Spectrometry. Rapid Comm. Mass Spectrom. 14:829-833

Stowers MA, Van Wuijckhuijse AL, Marijnissen JCM and Kientz CE (2002) Method and Device for Detecting and Identifying Bio-aerosol Particles in the Air. Patent WO/2002/052246 
Suess DT and Prather KA (1999) Mass Spectrometry of Aerosols. Chem. Rev. 99:3007-3035

Syage JA, Hanning-Lee MA and Hanold KA (2000) A Man-portable Photoionization Mass Spectrometer. Field Anal. Chem. Technol. 4:204-215

Szponar B and Larsson L (2001) Use of Mass Spectrometry for Characterising Microbial Communities in Bioaerosols. Ann. Agric. Environ. Med. 8:111-117

Tanaka K, Ido Y, Akita S, Yoshida Y and Yoshida T (1987) Development of Laser Ionization Time of Flight Mass Spectrometer IV - Generation of Quasi-Molecular Ions from High Mass Organic Compound. Proc. Second Japan-China Joint Symposium on Mass Spectrometry, Sept. 15-18, Osaka, Japan

Taylor J, Goodacre R, Wade WG, Rowland JJ and Kell DB (1998) The Deconvolution of Pyrolysis Mass Spectra Using Genetic Programming: Application to the Identification of Some Eubacterium Species. FEMS Microbiol. Lett. 160:237-246

Tegnell A, Van Loock F, Baka A, Wallyn S, Hendriks J, Werner A and Gouvras G (2006) Development of a Matrix to Evaluate the Threat of Biological Agents Used for Bioterrorism. Cell Mol. Life Sci. 63:2223-2228

Tobias HJ, Schafer MP, Pitesky M, Fergenson DP, Horn J, Frank M and Gard EE (2005) Bioaerosol Mass Spectrometry for Rapid Detection of Individual Airborne Mycobacterium tuberculosis H37Ra Particles. Appl. Environ. Microbiol. 71:6086-6095

Tobias HJ, Pitesky ME, Fergenson DP, Steele PT, Horn J, Frank M and Gard EE (2006) Following the Biochemical and Morphological Changes of Bacillus atrophaeus Cells During the Sporulation Process using Bioaerosol Mass Spectrometry. J. Microbiol. Meth. 67:56-63

Tripathi A, Maswadeh WM and Snyder AP (2001) Optimization of Quartz Tube Pyrolysis Atmospheric Pressure Ionization Mass Spectrometry for the Generation of Bacterial Biomarkers. Rapid Commun. Mass Spectrom. $15: 1672-1680$

Uphoff A, Muskat T, Grotemeyer J (2004) Design, Setup and First Results of a Miniaturized Time-of-flight Mass Spectrometer with a Simple Reflector of a New Design. Eur. J. Mass Spectrom. 10:163-171

Valentine N, Wunschel S, Wunschel D, Petersen C and Wahl K (2005) Effect of Culture Conditions on Microorganism Identification by Matrix-assisted Laser Desorption Ionization Mass Spectrometry. Appl. Environ. Microbiol. 71:58-64

Van Baar BLM (2000) Characterisation of Bacteria by Matrix-assisted Laser Desorption/Ionisation and Electrospray Mass Spectrometry. FEMS Microbiol. Rev. 24:193-219

Van der Greef J, Tas AC, Ten Noever de Brauw MC (1988) Direct Chemical Ionization - Pattern Recognition: Characterization of Bacteria and Body Fluid Profiling. Biomed. Environm. Mass Spectrom. 16:45-50

Van Malderen H, Hoornaert S and Van Grieken R (1996) Identification of Individual Aerosol Particles Containing Cr, $\mathrm{Pb}$, and $\mathrm{Zn}$ above the Noth Sea. Environ. Sci. Technol. 30:489-498

Van Wuijckhuijse AL, Grootveld CJ, Weiss M, Marijnissen JCM and Scarlett B (1998) Improvements to the TOF Aerosol Mass Spectrometer. J. Aerosol Sci. 29, Suppl. 1:443-444

Van Wuijckhuijse AL, Stowers MA, Kleefsman WA, Van Baar BL M, Kientz CE and Marijnissen JCM (2005a) MatrixAssisted Laser Desorption/Ionisation Aerosol Time-of-flight Mass Spectrometry for the Analysis of Bioaerosols: Development of a Fast Detector for Airborne Biological Pathogens. J. Aerosol Sci. 36:677-687

Van Wuijckhuijse A, Kientz C, Van Baar B, Kievit O, Busker R, Stowers M, Kleefsman W and Marijnissen J (2005b) Development of Bioaerosol Alarming Detector. Proc. NATO Adv. Res. Workshop on Defense Against Bioterror: Detection Technologies, Implementation Strategies and Commercial Opportunities, 8-11 April 2004, Madrid, Spain, In: Morrison D, Milanovich F, Ivnitski D, Austin TR (eds) NATO Security through Science Series B: Physics and Biophysics, vol 1. Springer, Berlin, pp 119-128

Van Wuijckhuijse AL, Kientz CE, Van Baar BLM et al., paper in preparation

Wang ZP, Russon L, Li L, Roser DC and Long SR (1998) Investigation of Spectral Reproducibility in Direct Analysis of Bacteria Proteins by Matrix-assisted Laser Desorption/Ionization Time-of-flight Mass Spectrometry. Rapid Commun. Mass Spectrom. 12:456-464

Wechsung R, Hillenkamp F, Kaufmann R, Nitsche R, Unsöld E and Vogt H (1978) LAMMA - A New LaserMicroprobe-Mass-Analyzer. Microscopica Acta (Suppl) 2:281-296

Weiss M, Marijnissen JCM, Verheijen PJT and Scarlett B (1993) On-line Measurement of Particle Size and Composition. J. Aerosol Sci. 24 (Suppl) 1:201-202

Weiss M (1997) An On-line Mass Spectrometer for Aerosols. Masters Thesis, Delft University of Technology, pp $122-131$

Westman A, Huth-Fehre T, Demirev P and Sundqvist BUR (1995) Sample Morphology Effects in Matrix-assisted Laser Desorption/Ionization Mass Spectrometry of Proteins. J. Mass Spectrom. 30:206-211

Wieser P, Wurster R and Seiler H (1980) Identification of Airborne Particles by Laser Induced Mass Spectroscopy. Atmospheric Environm. 14:485-494

Wieten G, Haverkamp J, Meuzelaar HLC, Bondwijn HW and Berwald LG (1981) Pyrolysis Mass Spectrometry: A New Method to Differentiate Between the Mycobacteria of the "Tuberculosis Complex" and Other Mycobacteria. J. Gen. Microbiol. 122:109-118 
Wilkes JG, Rushing LG, Gagnon J-F, McCarthy SA, Rafii F, Khan AA, Kaysner CA, Heinze TM and Sutherland JB (2005a) Rapid Phenotypic Characterization of Vibrio Isolates by Pyrolysis Metastable Atom Bombardment Mass Spectrometry. Antonie van Leeuwenhoek 88:151-161

Wilkes JG, Rushing L, Nayak R, Buzatu DA and Sutherland JB (2005b) Rapid Phenotypic Characterization of Salmonella enterica Strains by Pyrolysis Metastable Atom Bombardment Mass Spectrometry with Multivariate Statistical and Artificial Neural Network Pattern Recognition. J. Microbiol. Methods 61:321-334

Wilkes JG, Rafii F, Sutherland JB, Rushing LG and Buzatu DA (2006) Pyrolysis Mass Spectrometry for Distinguishing Potential Hoax materials from Bioterror Agents. Rapid Commun. Mass Spectrom. 20:2383-2386

Williams TL, Andrzejewski D, Lay Jr. JO and Musser SM (2003) Experimental Factors Affecting the Quality and Reproducibility of MALDI TOF Mass Spectra Obtained from Whole Bacteria Cells. J. Am. Soc. Mass Spectrom. $14: 342-351$

Wunschel DS, Hill EA, McLean JS, Jarman K, Gorby YA, Valentine N and Wahl K (2005a) Effects of Varied $\mathrm{pH}$, Growth Rate and Temperature Using Controlled Fermentation and Batch Culture on Matrix Assisted Laser Desorption/Ionization Whole Cell Protein Fingerprints. J. Microbiol. Meth. 62:259-271

Wunschel SC, Jarman KH, Petersen CE, Valentine NB, Wahl KL, Schauki D, Jackman J, Nelson CP and White 5th E (2005b) Bacterial Analysis by MALDI-TOF Mass Spectrometry: An Inter-laboratory Comparison. J. Am. Soc. Mass Spectrom. 16:456-462

Yang M, Dale JM, Whitten WB and Ramsey JM (1995) Laser Desorption Tandem Mass Spectrometry of Individual Microparticles in an Ion Trap Mass Spectrometer. Anal. Chem. 67:4330-4334

Zakett D, Schoen AE, Cooks RG and Hemberger PH (1981) Laser-Desorption Mass Spectrometry / Mass Spectrometry and the Mechanism of Desorption Ionization. J. Am. Chem. Soc. 103:1295-1297

Zhang H and Caprioli RM (1996) Capillary Electrophoresis Combined with Matrix-Assisted Laser Desorption/Ionization Mass Spectrometry, Continuous Sample Deposition on a Matrix-precoated Membrane Target. J. Mass Spectrom. 31:1039-1046

Zoller DL, Sum ST, Johnston MV, Hatfield GR and Qian K (1999) Determination of Polymer Type and Comonomer Content in Polyethylenes by Pyrolysis - Photoinization Mass Spectrometry. Anal. Chem. 71:866-872 